UNIVERSIDADE DE SÃO PAULO

FACULDADE DE FILOSOFIA, LETRAS E CIÊNCIAS HUMANAS

DEPARTAMENTO DE CIÊNCIA POLÍTICA

ANDRÉA JUNQUEIRA MACHADO

OS DETERMINANTES DA ATUAÇÃO OPOSICIONISTA EM DEMOCRACIAS: O CASO BRASILEIRO

Versão corrigida

SÃO PAULO

2017 


\section{OS DETERMINANTES DA ATUAÇÃO OPOSICIONISTA EM DEMOCRACIAS: O CASO BRASILEIRO}

Dissertação apresentada à Faculdade de Filosofia, Letras e Ciências Humanas da Universidade de São Paulo para a obtenção do título de mestre em Ciência Política.

Orientadores:

Prof. Dr. Fernando de Magalhães Papaterra Limongi

Prof. . . Dr ${ }^{\mathrm{a}}$. Andréa Marcondes de Freitas

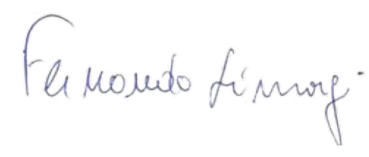

De acordo com a revisão

São Paulo, 22 de Agosto de 2017

Versão corrigida

SÃO PAULO

2017 
Autorizo a reprodução e divulgação total ou parcial deste trabalho, por qualquer meio convencional ou eletrônico, para fins de estudo e pesquisa, desde que citada a fonte.

Catalogação na Publicação

Serviço de Biblioteca e Documentação

Faculdade de Filosofia, Letras e Ciências Humanas da Universidade de São Paulo

Junqueira, Andréa Machado

Jd Os determinantes da atuação oposicionista em democracias: o caso brasileiro / Andréa Machado Junqueira ; orientador Fernando Limongi. - São Paulo, 2017.

$80 \mathrm{f}$.

Dissertação (Mestrado) - Faculdade de Filosofia, Letras e Ciências Humanas da Universidade de São Paulo. Departamento de Ciência Política. Área de concentração: Ciência Política.

1. Oposição. 2. Minoria. 3. Maioria. 4. Coalizão. 5. Comissão. I. Limongi, Fernando, orient. II. Título. 
Nome: JUNQUEIRA, Andréa Machado

Título: Os determinantes da atuação oposicionista em democracias: o caso brasileiro

Dissertação apresentada à Faculdade de Filosofia, Letras e Ciências Humanas da Universidade de São Paulo para a obtenção do título de mestre em Ciência Política.

Aprovado em:

Banca Examinadora

Professor Dr:

Instituição:

Julgamento:

Assinatura:

Professor Dr:

Instituição:

Julgamento:

Assinatura:

Professor Dr:

Instituição:

Julgamento:

Assinatura: 
Aos meus pais, Rose e Menezes, às minhas irmãs, Clara e Claudia, e ao Luis 


\section{AGRADECIMENTOS}

Escrever uma dissertação é um processo sofrido. Cada nova versão do arquivo em word guarda as angústias do processo de escrita, as reconsiderações, os trechos que tiveram de ser reavaliados e as incontáveis discussões entre nós mesmos e os vários autores lidos, que ecoam incansavelmente em nossas mentes. Mas não só. Guardam também os momentos de descoberta, de alegria, de absoluta satisfação, que eu jamais teria não fossem as pessoas que eu tive a felicidade de conhecer.

Em primeiro lugar, agradeço à minha orientadora, Andréa Freitas. Andréa, eu não tenho palavras para descrever a quão grata eu sou a você. Há cinco anos eu entrei no NECI, sem nunca ter tido qualquer contato com pesquisa, e você, com sua incrível dedicação e capacidade, me pegou pela mão e me abriu as portas para um novo mundo. Não há uma frase sequer nessa dissertação que não possa ser remetida a alguma de nossas conversas. Sou incrivelmente grata por ter tido o privilégio de trabalhar tantos anos com uma pessoa tão inspiradora quanto você. É sem medo que eu digo que você mudou a minha vida.

Ao meu orientador, Fernando Limongi. Professor, agradeço pelas muitas conversas, pelos comentários sempre afiados, pela atenção com que leu às muitas versões dessa dissertação e pela paciência. A sua orientação pode ser notada em todas as páginas deste trabalho, mas é especialmente evidente no capítulo dois. Agradeço por ter me incentivado a enveredar para a análise de mudanças institucionais, agenda que pretendo perseguir.

À professora Marta Arretche, pelos ótimos pontos levantados na banca de qualificação e por sua dedicação integral aos alunos do departamento. Ao professor Adrian Lavalle, por ter ministrado a disciplina que ofereceu o substrato para as análises que empreendo nesta dissertação. Ao professor Glauco, por manter a porta da sua sala sempre aberta e por ter me feito pensar no meu problema de pesquisa de modo estruturado, ensinamento valioso que busquei aplicar neste trabalho.

Sou imensamente grata por fazer parte de um grupo como o NECI. Foi na nossa salinha que aprendi que a melhor maneira de fazer pesquisa é com estreita colaboração. Com cada um de vocês, todos os dias, aprendi muito, e encontrei amigos para a vida toda. Fernanda, minha grande amiga, agradeço pelas (literalmente) incontáveis conversas, por ter me mantido sã durante todo esse processo e por seu imenso carinho. 
Ter você como amiga é uma grande felicidade e privilégio. Minha admiração por você é enorme e só cresce. Obrigada por fazer parte da minha vida.

Joyce, amiga querida, pessoa de generosidade e dedicação de grandeza ímpar, devo tanto a você que não sei por onde começar. Sou absolutamente grata por seus muitos comentários a essa dissertação, pelas tardes que passou comigo me ensinando a fazer os gráficos no R, pelas palavras de carinho e por ter "segurado as pontas" quando eu mais precisei. É com convicção que eu digo que não teria conseguido sem você.

Danilo, mesmo de longe sempre arranjou um jeito de ajudar os que ficaram. Muito obrigada pelos comentários e por ter feito do nosso grupo o que ele é hoje. Pedro, agradeço muito por todo o apoio, pela incansável coleta de dados e pela dedicação com que sempre ajuda a todos. Ana Beatriz, muito obrigada pela companhia e pela prontidão com que me ajudou com os dados sobre comissão. Maurício, agradeço pelos muitos anos de ajuda com matemática e estatística. Patrick, obrigada pelos comentários feitos a uma das muitas versões do que é hoje o primeiro capítulo. Ju, a pessoa que transformou o NECI em um lugar muito mais feliz e saudável, muito obrigada pelo carinho e por manter nossa sala sempre funcionando. Cassio, obrigada pelas risadas e por ser essa pessoa incrível. Samir e Grazi, muito obrigada pela amizade.

Agradeço também à nova turma do NECI, por me ensinarem tanto. Vocês me enchem de orgulho: Ligiane, Vanessa, Nathan, Camila, Leo, Alexia, Rodrigo, Gabriel Z. e Gi que, embora não esteja mais na sala, continua nos nossos corações. Agradeço especialmente à Vanessa por ter coletados parte dos dados sobre dispositivos utilizados nesta dissertação, só nós sabemos o quão sofrido é esse processo, e à Ligiane e à Ana, por diariamente recolherem muitos dos dados que eu usei aqui. Ao Davi, o mais novo membro da nossa querida salinha, obrigada pela dedicação com que assumiu os nossos bancos.

Devo um agradecimento especial ao Sérgio Simoni, o melhor comentador de pôsteres já visto, por todos os seus apontamentos no decorrer dos últimos cinco anos.

Pelo apoio institucional agradeço aos funcionários e amigos do departamento: Vasne, Márcia e Leo. À Fundação de Amparo à Pesquisa do Estado de São Paulo (FAPESP) agradeço pela concessão da bolsa de mestrado, registrada pelo número de processo 2014/23987-8, e por todo o apoio financeiro para a realização desta pesquisa ${ }^{1}$.

\footnotetext{
${ }^{1}$ As opiniões, hipóteses e conclusões ou recomendações expressas neste material são de responsabilidade da autora e não necessariamente refletem a visão da FAPESP.
} 
Ao querido Luis. Acho que ninguém leu tantas vezes este trabalho quanto você. Muito obrigada pelos inúmeros comentários e pelo enorme carinho durante todos esses muitos anos. É claro, também por ter transformado os terríveis desenhos que eu fiz em uma folha de caderno nas belíssimas figuras do capítulo dois. Eu não teria chegado aqui sem você.

Finalmente, agradeço aos meus pais, Rose e Menezes, por seu apoio, dedicação e amor incondicionais. Vocês me enchem de orgulho todos os dias. Às minhas irmãs, Clara e Claudia, pelo sempre incentivo e carinho, e à minha prima, Mariana, pelas muitas risadas. Vocês são minha vida. 


\section{RESUMO}

JUNQUEIRA, A. M. (2017). Os determinantes da atuação oposicionista em democracias: o caso brasileiro. Dissertação de Mestrado. Faculdade de Filosofia, Letras e Ciências Humanas, Universidade de São Paulo, São Paulo.

O presente trabalho visa estabelecer quais são as condições responsáveis por permitir à oposição o poder de influenciar o processo decisório em Legislativos. Para tanto, a pesquisa se divide em duas frentes, a primeira teórica e a segunda empírica. Em campo teórico o trabalho chama a atenção para a inviolabilidade do princípio majoritário no que diz respeito à produção legislativa e às suas regras regimentais e, por fim, demonstra como a sua desconsideração pode levar a equívocos no tocante à expectativa sobre o comportamento dos diversos atores envolvidos. Em solo empírico, demonstrarse-á que a incorporação deste princípio é essencial para compreendermos de que maneira a oposição pode intervir no processo decisório, assim como quando e porquê acontecerão mudanças regimentais que aumentem ou restrinjam os direitos da minoria.

Palavras-chave: Oposição; Minoria; Maioria; Coalizão; Comissão. 


\begin{abstract}
JUNQUEIRA, A. M. (2017). The determinants of oppositional performance in democracies: the Brazilian case. Dissertação de Mestrado. Faculdade de Filosofia, Letras e Ciências Humanas, Universidade de São Paulo, São Paulo.

The present thesis aims to establish the conditions that give oppositions the power to influence the decision-making process in Legislatives. Our research will be presented in two views, the first theoretical and the second, empirical. On the theoretical view, the study draws attention to inviolability of the majority principle in conducing the legislative process and its regimental rules and ultimately, how disregarding it can lead to mistakes in expectations of involved actors' behavior. On the empirical view it will be shown that embedding that principle is essential to understand in which way the opposition can intervene in the decision-making process, as well as how and why regimental changes will happen either to restrict or to widen the minority rights.
\end{abstract}

Keywords: Opposition; Minority; Majority; Coalition; Committee. 


\section{Lista de Gráficos}

Gráfico 1 - Padrão de Alteração: Coalizão e Oposição .................................................................. 37

Gráfico 2 - Proporção de alterações realizadas em comissão e plenário ....................................... 38

Gráfico 3 - Proporção de Alterações Realizadas na Comissão: Coalizão e Oposição................. 39

Gráfico 4 - Número de Alterações realizadas por relator e parlamentar por coalizão e oposição

Gráfico 5 - Tamanho da Oposição na Câmara dos Deputados ................................................... 42

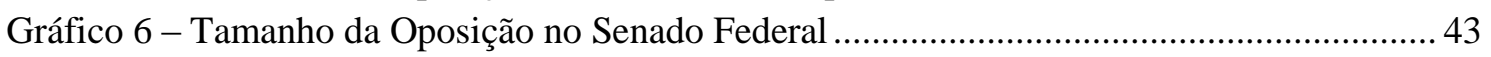

Gráfico 7 - Relação entre relatores e apresentação de substitutivo ............................................. 44

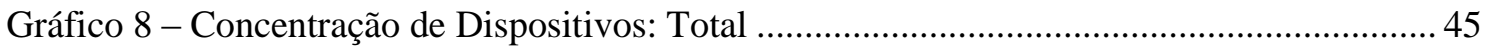

Gráfico 9 - Concentração de Dispositivos: Projetos mais alterados por grupo ........................... 46 


\section{Lista de Tabelas}

Tabela 1 - Número de projetos analisados e dispositivos por categoria de projeto ...................... 35

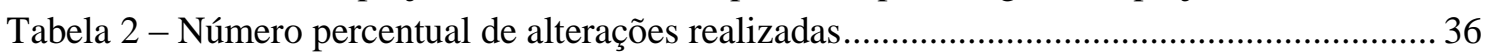

Tabela 3 - Número percentual de alterações realizadas por relator e parlamentar ...................... 40

Tabela 4 - Projetos mais alterados pela coalizão (decil superior).............................................. 48

Tabela 5 - Projetos mais alterados pela oposição (decil superior) ............................................. 50 


\section{Lista de Figuras}

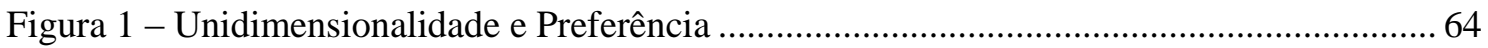

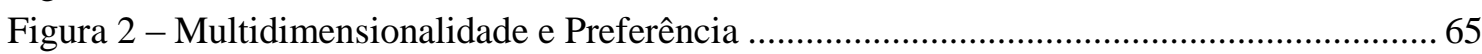

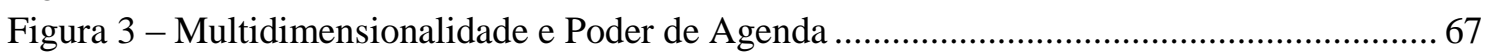




\section{Sumário}

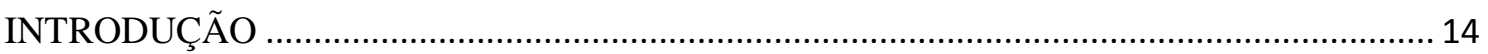

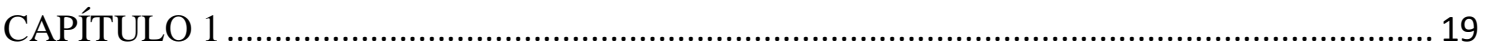

Desvendando o Papel da Estrutura de Comissões para a atuação da Oposição .................. 19

1.1. Relação entre descentralização e capacidades do Legislativo ......................................... 26

1.2. O caso brasileiro: descentralização e centralização ....................................................... 27

1.3. Se não nas comissões, onde? O lugar da oposição........................................................ 31

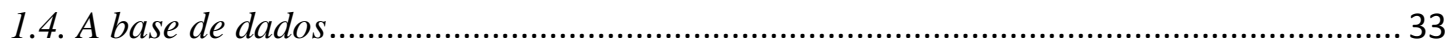

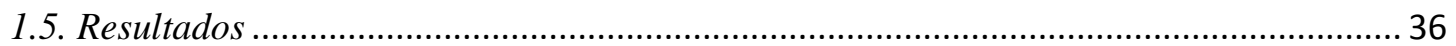

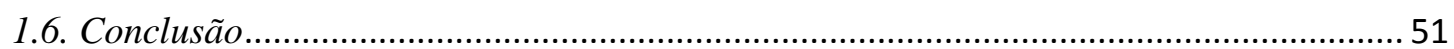

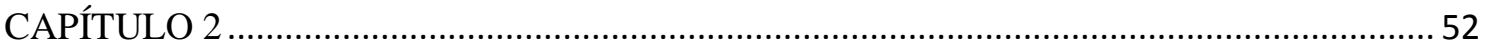

O Princípio Majoritário Alcança os Procedimentos: Restrição ao Poder da Minoria ....... 52

2.1. O princípio majoritário em ação na Câmara dos Deputados: O Destaque para Votação

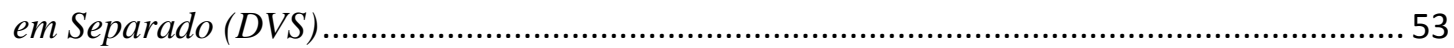

2.2. Quando ocorrerão reformas procedimentais? Explicando o timing das mudanças......... 61

2.3. Câmara dos Deputados: Uma Instituição Majoritária .................................................... 68

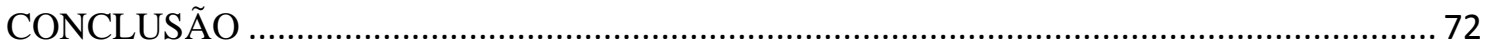

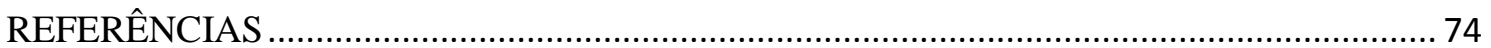

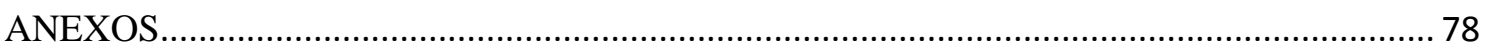

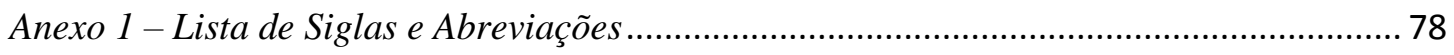

Anexo 2 - Coalizões governamentais no Brasil (1988-2014).................................................. 79 


\section{INTRODUÇÃO}

O presente trabalho possui como objetivo estabelecer quais são as condições responsáveis por permitir à oposição poder de influenciar o processo de tomada de decisão no interior do Legislativo. Para a teoria democrática, a relevância do tema é inegável (DAHL, 1969; MANIN, 2007). Para a teoria positiva, a discussão é ainda subdesenvolvida. A contribuição pretendida com essa dissertação é no campo da teoria positiva e se divide em duas modalidades, a primeira teórica e a segunda empírica. Em campo teórico, defendo uma estratégia analítica que tome a sério o princípio da maioria, incorporando-o à análise dos estudos legislativos em sentido amplo. Em solo empírico, busco revelar quais predições sobre o comportamento da oposição, quando considerado o princípio majoritário, são confirmadas pelos dados reunidos sobre o Congresso brasileiro. Especificamente, mostro que a maioria controla o processo legislativo e que a atuação da minoria, embora restrita, não é nula.

Provém de Krehbiel (1992) a assertiva segundo a qual o princípio da maioria é inviolável. Apesar de simples, o enunciado possui enorme alcance. A regra da maioria é uma constante em Legislativos e alcança tanto a decisão sobre políticas, quanto a escolha pelos procedimentos que regerão aquela. Assim sendo, embora a manutenção do status quo, em casos circunscritos, possa se fazer pela vontade da minoria - caso se faça presente a necessidade de quórum especial ${ }^{2}-$, a mudança, motor da política, só é possível se pela vontade majoritária. A produção de políticas públicas em desacordo com aquilo desejado pela maioria, bem como a existência de regras procedimentais que impeçam a concretização dos anseios majoritários são, portanto, instáveis, visto que caracterizados por uma situação de não equilíbrio. Em que pesem as possíveis críticas ao modelo de Krehbiel (1992), dentre as quais as mais graves se referem à desconsideração do impacto das regras herdadas sobre o arranjo institucional presente e a desimportância conferida ao elemento partidário (BINDER, 1997), o princípio majoritário, mesmo no tocante a alterações institucionais, é de grande valia para o entendimento do problema de pesquisa aqui perseguido.

O Congresso Nacional, sendo parte da estrutura institucional do arranjo democrático, fatalmente deve se submeter ao primeiro dos princípios da democracia: as decisões devem ser tomadas em concordância com a maioria. O imperativo majoritário,

\footnotetext{
${ }^{2}$ Mudanças constitucionais usualmente exigem amplas maiorias e, como a regra que disciplina alterações na constituição encontra-se também estabelecida constitucionalmente, a uma maioria estrita, de 50\% mais um, é vedado o direito de alteração do status quo constitucional.
} 
portanto, impede a tomada de decisão por minorias. Em razão da onipresença da regra da maioria, argumento que a capacidade de ação de não membros da coalizão de governo irá depender sobremaneira de sua habilidade de aliar-se com o maior número. À primeira vista, a assertiva parece trivial, mas não é.

Coalizão é um termo relativamente incontroverso. No Brasil, convencionou-se, tal qual em parlamentarismos, a utilização do critério baseado na detenção de pastas ministeriais. Se um partido possui sob seu comando ao menos um ministério, este é considerado membro da coalizão governista e, simetricamente, se não o detém, integrante da oposição. Para a definição da coalizão, o critério parece servir a contento, visto que, ao chamar um partido para ocupar um ministério, o presidente assinala sua disposição de negociar e, ao aceitar o convite, a legenda convidada sela o acordo. A base governista, portanto, se forma a partir do consentimento oferecido pelos partidos integrantes. O termo oposição, por seu turno, envolve alta dose de ambiguidade. A oposição, comumente entendida como os partidos sem pastas ministeriais, diferentemente da coalizão, não necessariamente sela qualquer compromisso em seu seio e, no mais, pode assemelhar-se a uma massa disforme, sem interesses compartilhados. Assim, coalizão e oposição são termos distintos do ponto de vista analítico. Enquanto aquele presume o acordo, este não passa de um desdobramento daquele, e possui pouca carga de significado. Insisto. $\mathrm{O}$ critério baseado na detenção de pastas ministeriais informa sobre a coalizão, mas é insuficiente para lançar luz sobre a oposição. O complemento da coalizão governista, para ser nomeado, depende do recurso ao neologismo. Trata-se da não-coalizão-governista, e não da oposição.

Ademais, não raro são tratados como sinônimos também os termos coalizão e maioria, de um lado, e oposição e minoria, de outro, provavelmente em decorrência de uma importação norte-americana, mal adaptada ao contexto de presidencialismos multipartidários (MORGENSTERN et al, 2008). Vale ressaltar que coalizões podem ser majoritárias ou minoritárias. Se a coalizão é majoritária, a não-coalizão é necessariamente minoritária e a oposição, como parte da não-coalizão, logicamente também é. A questão ganha em complexidade quando a coalizão governista é minoritária. Nesse caso, a não-coalizão, possivelmente um agrupamento sem qualquer coesão, é majoritária, mas isso não quer dizer que a oposição o seja. Não pertencer à coalizão não implica em pertencimento à oposição, já que não é este o complemento daquela. Como atesta Strøm (1990) sobre a ocorrência de governos minoritários, partidos que não desfrutam de cargos no Executivo podem, todavia, oferecer seu apoio 
no Legislativo. Inclusive, essa é a condição para a manutenção de governos minoritários em sistemas parlamentaristas, qual seja, um apoio legislativo majoritário, seja ele estável ou construído de maneira ad hoc.

Tendo em vista a fluidez do termo oposição, é preciso que fique clara a definição do objeto alvo da investigação aqui pretendida. Embora se reconheça, conforme parágrafos anteriores, que a não-coalizão-governista é multifacetada, este trabalho encara como oposição todos os partidos não detentores de pastas ministeriais. A escolha por fundir os dois conceitos é motivada por questões teóricas e operacionais. Do ponto de vista teórico, tendo em vista os diversos recursos acessíveis à presidência e aos partidos parceiros desta, é objetivo da presente pesquisa descobrir de que maneira as legendas desprovidas dos mesmos instrumentos podem afetar a política pública produzida. Desse modo, para os fins perseguidos, importa mais a desigualdade de recursos e menos o posicionamento do partido - se de oposição declarada ou comedida - em relação à coalizão governista. No que diz respeito ao aspecto operacional, a fusão dos conceitos permite que se escape à dificuldade de distinguir a retórica do partido de sua real atividade no Legislativo. Não raro partidos assinalam à sociedade postura hostil em relação ao Executivo embora, com frequência, atuem junto deste em diversas questões. Estabelecido o conceito, a partir desse momento, o termo oposição deve ser entendido como um sinônimo de não-coalizão.

Parte considerável da literatura voltada à atuação da oposição assinalou supostos arranjos institucionais propícios à intervenção oposicionista, dentre os quais se destaca a estrutura de comissões. Os estudos distributivistas sobre o Congresso americano, ao argumentarem que as decisões são tomadas nas comissões por parlamentares cujas preferências distam das presentes na maioria do plenário, cometem um erro analítico, qual seja, ignoram o princípio majoritário. O equívoco, embora de outra natureza, também marca a interpretação de Strøm (1990) sobre a capacidade de ação da oposição. Ao não diferenciar oposição de minoria, o autor atribui à estrutura de comissões a origem de parte da capacidade de ação da oposição, quando em realidade, buscar-se-á demonstrar que o fenômeno se explica à luz da regra da maioria. É urgente que os conceitos oposição e minoria, bem como os coalizão e maioria, sejam distinguidos, sob o risco de continuarmos empreendendo interpretações equivocadas sobre o agir da oposição, erro de partida cometido por parte da literatura que se voltou à compreensão do fenômeno. 
Argumentar que o princípio majoritário é incontornável apenas nos diz que, sem uma maioria, decisões não podem ser tomadas, contudo, se é possível que o threshold necessário à aprovação seja obtido apenas com os votos governistas, continua a oposição tendo vez? Dito de outro modo, tratam-se de maiorias mínimas? Assumindo como premissa que as preferências dos parlamentares obedecem a um modelo espacial multidimensional, se diferentes maiorias se formam em resposta a cada nova decisão alvo de deliberação, somente os sujeitos com preferências extremadas em todos os setores de política seriam permanentemente privados de assistirem às suas políticas preferidas vitoriosas em plenário. Todavia, se o comportamento é regido pela lógica partidária e um acordo estável entre as legendas é firmado, uma nova configuração se apresenta: governo versus oposição. Se é verdade que no Legislativo a maioria é soberana, a existência de uma coalizão de governo majoritária e coesa colocaria a oposição permanentemente a reboque daquilo preferido pela base governista? A lógica do cartel legislativo é capaz de explicar o funcionamento do Congresso? Argumento que não.

Seguindo a trilha de Aldrich e Rohde (2000), não há motivos para acreditarmos que a coalizão governista terá interesse em intervir em todas as matérias em tramitação. Se a diferenciação entre as agremiações - governo e oposição - for diminuta, impedir que parlamentares oposicionistas contribuam seria um esforço despropositado. Ainda, se a coesão da base de governo em determinada proposta for baixa, parlamentares da coalizão podem se ver mais próximos de membros oposição do que de seus próprios parceiros, situação também capaz de refrear qualquer possível investida da coalizão contra a intervenção da oposição. Assim, a noção de governo partidário condicional elaborada pelos autores é de grande valia para entendermos o lugar da oposição em Legislativos, inclusive no brasileiro.

Pesquisas que utilizam como unidade de análise fundamental o partido político destacam que são as legendas o mote estruturador do processo legislativo. Cox e McCubbins (1993), tendo por referência o Legislativo americano, atribuem ao partido majoritário o poder de coordenar os trabalhos. Para o caso brasileiro, Figueiredo e Limongi (1999) argumentam que as características do arranjo institucional pós 1988, cujo cerne é a centralização do processo decisório, criaram incentivos para a formação de coalizões estáveis, conferindo ao presidente e à sua base primazia sobre a agenda legislativa. Desse modo, em oposição a um Congresso caracterizado pelo individualismo e consequente fraqueza dos partidos (LAMOUNIER, 1992, 1994; 
AMES, 1995, 2003), um outro modelo explicativo foi apresentado, no qual o conflito não se resume a disputas sobre quem levará o bacon para o seu eleitorado em um cenário de recursos escassos, mas sim é traduzido em uma disputa entre os de dentro e os de fora da base governista. Não se pretende aqui negar o poder explicativo da vertente partidária, mas sim delimitar o seu alcance. Como será discutido, a depender do teor da matéria alvo de deliberação, a coalizão possui maior ou menor interesse em intervir. Mais especificamente, a oposição possui pouca participação em matérias presentes na agenda prioritária da coalizão. Nos termos de King (1976), aqui estamos no opposition mode, modo de relação entre governo e oposição caracterizado pelo conflito. Há, entretanto, um segundo leque de proposições que, para tornar-se inteligível, depende que extrapolemos a noção de conflito. Há uma gama de projetos em tramitação nos quais a colaboração entre coalizão e oposição é a norma. Desse modo, para compreendermos o comportamento da oposição devemos superar a noção estrita de antagonismo entre os grupos.

Entender a atuação daqueles não pertencentes à coalizão de governo depende, portanto, de conciliar os achados da corrente partidária a uma noção mais detida sobre o princípio majoritário. O mecanismo colocado em marcha para que decisões sejam tomadas passa pela ação dos partidos, não obstante, sem referência à regra da maioria, a engrenagem não é integralmente compreendida, especialmente no que diz respeito ao comportamento dos partidos que não integram a coalizão. Dado que todas as decisões apontam para o plenário - ou assim podem sê-lo, se requerido pela maioria ${ }^{3}$ - a alusão às comissões não dá conta de explicar o que se pretende. Ademais, para além dos conflitos estritamente partidários que, não raro, polarizam o debate entre governo e oposição, há ainda uma gama de matérias em que a dicotomia é diluída e a ação conjunta se transforma em norma.

O presente trabalho está dividido em, além desta introdução, dois capítulos. No primeiro será discutido o efeito, no que diz respeito à atuação da oposição, da interação entre, de um lado, a estrutura de comissões e, de outro, o princípio majoritário. No segundo, o objetivo é debater o impacto do princípio majoritário sobre a mudança e estabilidade institucional no tocante aos direitos da minoria.

\footnotetext{
${ }^{3} \mathrm{Na}$ Câmara dos Deputados, o pedido de urgência e o requerimento capaz de anular o poder terminativo das comissões são mecanismos por meio dos quais a maioria pode exigir deliberar em plenário sobre a matéria.
} 


\section{CAPÍTULO 1}

\section{Desvendando o Papel da Estrutura de Comissões para a atuação da Oposição}

Qual é o papel de minorias em processos decisórios legislativos? A resposta a essa pergunta variou e, a cada nova tentativa de respondê-la, conceitos bem adaptados ao seu contexto original foram transportados para outros, sem o devido cuidado. Nos termos de Sartori (1970), a atenção ao significado dos conceitos e suas implicações deu lugar ao conceptual stretching. Especificamente, os termos minoria e oposição foram fundidos, operação que custou caro à compreensão do fenômeno em questão.

Ainda, outra confusão conceitual dificultou que a pergunta enunciada pudesse ser satisfatoriamente respondida, refiro-me às inúmeras definições do que seriam “comissões fortes" e o impacto destas sobre o processo decisório.

Para que possamos estabelecer o lugar da minoria, ou da oposição, em Legislativos, é preciso que antes limpemos o terreno em âmbito teórico, para que então tenhamos condições de elaborar hipóteses a serem testadas empiricamente. Para tanto, na presente introdução seguirei o seguinte caminho: primeiro, discutirei como a corrente distributivista, temporalmente a primeira a oferecer um modelo completo sobre o funcionamento do Congresso americano, lidou com a questão da minoria. Segundo, demonstrarei como abordagens posteriores foram influenciadas pelos estudos distributivistas, e como incorporaram conceitos a novos contextos sem a devida cautela - argumento que a plasticidade dos termos produziu falhas no que diz respeito às expectativas sobre o comportamento dos atores. Terceiro, argumentarei em favor de uma explicação que tome a sério o princípio majoritário. Defendo que o poder de influência da oposição não é determinado pela estrutura de comissões (descentralização), mas sim por sua capacidade de aliar-se à maioria.

Como notam Mattson e Strøm (1995:303), a estrutura de comissões é considerada uma das características mais significativas dos parlamentos modernos. Inúmeros são os trabalhos que argumentaram que comissões fortes são cruciais para a ação da oposição e minorias (MAYHEW, 1975; STRØM, 1990; POWELL, 2000), ou assumiram tal assertiva como fato consumado (GIULJ, 1981; LAVER \& SCHOFIELD, 1991; ANDEWEG, 2008; HELMS, 2008; TUTTNAUER, 2014, 2015; MAEDA, 2015). É objetivo deste capítulo esmiuçar como foi construída pela literatura especializada a relação entre comissões, de um lado, e capacidade de ação de minorias e da oposição, de outro, esclarecendo quais são as implicações teóricas e empíricas quando a distinção 
entre os dois últimos conceitos não é tomada a sério, situação usual nos estudos sobre o assunto.

Sobre a relação entre a estrutura de comissões e o poder de intervenção de minorias, a perspectiva distributivista é clara: as comissões permitem que decisões sobre políticas públicas sejam tomadas por uma fração dos parlamentares, ainda que a escolha tomada esteja em desacordo com a preferência da maioria dos congressistas. $\mathrm{O}$ mecanismo responsável por criar um ambiente no qual minorias, e não maiorias, decidem sobre o conteúdo da legislação produzida é conhecido. A heterogeneidade de preferências dos parlamentares, derivada da heterogeneidade de preferências entre as constituencies de cada congressista, criariam a oportunidade para que ganhos de troca fossem obtidos. Uma vez que a sorte eleitoral de cada parlamentar depende apenas de seu distrito, pareceria vantajoso ao parlamentar abdicar de sua prerrogativa para decidir sobre matérias pouco relevantes para seus eleitores, em favor de um maior poder de influência sobre a legislação de interesse de sua constituency. As comissões, por garantirem que parcelas do total tenham precedência sobre a política elaborada em cada uma das áreas temáticas, cimentariam o acordo; parlamentares aprovariam em plenário a legislação provinda de outras comissões que não a sua, mesmo que esta esteja afastada de sua preferência, na esperança de que seus pares façam o mesmo quando do momento da votação de matéria originada por sua própria committee (MAYHEW, 1975; SHEPSLE \& WEINGAST, 1994) ${ }^{4}$. Para os distributivistas, desse modo, as comissões permitem que sejam alcançados resultados antimajoritários, em outras palavras, que as preferências de minorias prevaleçam sobre as da maioria.

Uma vez que, para a abordagem distributivista, o elemento partidário é considerado desimportante para explicar a organização dos trabalhos legislativos, o conceito minoria não deve ser tomado como sinônimo de oposição. Todavia, ainda que consideremos que partidos são irrelevantes no que diz respeito aos resultados produzidos pelo Congresso (KREHBIEL, 1993), a presença de representação partidária no Legislativo é uma realidade empírica incontestável. Desse modo, seguindo o raciocínio da corrente distributivista, teríamos de concluir que o partido minoritário na Câmara dos Deputados e/ou no Senado Federal, ou ainda aquele não detentor da presidência, não está alijado do poder. Em outras palavras, ainda que o elemento partidário não seja um aspecto considerado relevante, para os distributivistas, sujeitos

\footnotetext{
${ }^{4}$ Especificamente sobre a lógica do logrolling, ver Shepsle e Weingast, 1994.
} 
afiliados ao partido minoritário, independentemente se presidencial ou não, poderiam também afetar o status quo, visto que o fazem no interior das comissões temáticas. Portanto, uma estrutura de comissões fortalecida permite que minorias tomem decisões, minorias estas que compreendem todos os partidos políticos.

Levando o argumento ao seu limite, podemos examinar se é possível concluir que, para essa perspectiva, as comissões favorecem não somente as minorias, mas também a oposição, entendida como o conjunto dos partidos que não possui cargos no Executivo. Para tanto, um exercício de imaginação é requerido, de modo a criarmos o contrafactual: em um ambiente sem comissões a oposição teria mais dificuldades? A resposta não é inequívoca. Seria possível que a cada nova votação os parlamentares se aliassem de uma forma diferente, produzindo maiorias díspares a cada novo turno. Não obstante possível, essa hipótese não é plausível. Embora haja heterogeneidade no interior dos partidos, a realidade mostra que parlamentares de uma mesma legenda tendem a votar de maneira parecida. Se o motivo para tal comportamento é a existência de disciplina partidária (COX \& McCUBBINS, 1993) ou mera homogeneidade de preferências (KREHBIEL, 1993) não importa: se há uma divisão partidária no plenário, caso a oposição seja minoritária, tenderá a ser sistematicamente prejudicada. A existência da estrutura de comissões protegeria, então, os membros da oposição, se minoritários, de derrotas frequentes no plenário. E se a oposição fosse majoritária, o que seria o esperado? Nesse caso, a base de governo, ainda que em menor número, permaneceria influente dentro das comissões. Mantida a coerência interna do argumento distributivista, podemos concluir que a estrutura de comissões desafia o princípio majoritário, segundo o qual decisões em Legislativos devem ser tomadas pela maioria, e cria vantagens para a minoria, seja ela constituída pela oposição ou pela base de governo ${ }^{5}$.

A relação entre a estrutura de comissões e a capacidade de intervenção da oposição foi também concebida por estudos que defendem que os partidos políticos estruturam o processo decisório, e não as comissões. Sobre o poder de influência da oposição, Strøm (1990) elenca cinco características institucionais, todas referentes à estrutura de comissões. A existência de pelo menos dez comissões permanentes seria

\footnotetext{
${ }^{5}$ Krehbiel (1991) demonstra que o argumento distributivista é falho. A lógica do log-roll entre comissões e plenário depende de todas as comissões receberem o mesmo tratamento em plenário. Entretanto, o parlamentar individual não possui qualquer garantia de que, caso vote favoravelmente a uma política provinda de uma comissão que não a sua, outros farão o mesmo quando chegar o momento da política de sua comissão ser votada em plenário. Sem essa garantia não há estabilidade nos acordos.
} 
necessária à especialização e esta, por sua vez, precondição para um efetivo processo de tomada de decisão. Comissões com jurisdições fixas são também consideradas importantes para garantir o processo de especialização. Caso reflitam as divisões temáticas dos ministérios, conferem ainda mais poder de controle ao Congresso sobre as ações do Executivo. É também relevante que haja restrição ao número de comissões que cada parlamentar pode participar, sob o risco de comprometer, de novo, a especialização. Finalmente, a distribuição proporcional entre cadeiras nas comissões e a composição dos partidos no Legislativo permite que a oposição não seja despojada de participação. Enquanto as primeiras quatro características informam sobre a capacidade do Legislativo frente ao Executivo, garantindo que aquele não seja um mero carimbador das propostas deste, a última efetivamente informa sobre a capacidade da oposição (POWELL, 2000). O que Strøm (1990) argumenta, tendo em vista as características que mobiliza, é que a capacidade de ação da oposição depende de uma organização dos trabalhos legislativos que garanta a independência do Legislativo e, mais que isso, que possibilite que a oposição não seja suprimida pela ala governista no Congresso.

Podemos notar que a definição do que seriam "comissões fortes" para os distributivistas, de um lado, e para Strøm (1990) e Powell (2000), de outro, não coincide. Enquanto para aqueles uma comissão é forte quando possibilita que a vontade de uma minoria se sobreponha ao que seria a preferência do plenário, para estes a força das comissões se relaciona com suas capacidades institucionais para afetar a legislação. Como reconhecem Strøm (1990) e Powell (2000), é possível que as comissões sejam integralmente controladas pelo partido majoritário, não decidam contrariamente ao plenário e, ainda assim, sejam fortes. Embora as características elencadas para a tipificação de comissões como "fortes" difiram daquelas mobilizadas pelos distributivistas, há motivos para crer que Strøm (1990) e Powell (2000) foram influenciados por aqueles ao tratarem da questão da oposição.

Buscando dar respostas ao enigma que representavam os governos minoritários em parlamentarismos, é plausível supor que Strøm (1990) tenha incorporado a relação entre comissões fortes e poder das minorias criada pela ciência política estadunidense, mas agora, ao invés de "minoria", a palavra da vez foi "oposição". Para o autor, a existência de governos minoritários em parlamentarismos exigia que a seguinte pergunta fosse respondida: assumida a premissa da racionalidade dos atores, por que partidos sem pastas no Executivo permitiriam que um governo minoritário permanecesse no poder, se podem a qualquer momento derrubá-lo? O autor elaborou 
uma resposta em duas frentes, a primeira demonstrando os custos de se fazer parte do governo, a segunda argumentando ser possível influenciar políticas via Legislativo, no interior das comissões. O autor é convincente ao discutir sobre os custos envolvidos com a incumbência, mas falha ao demonstrar que a influência da oposição se deve à estrutura de comissões, e não ao status minoritário da coalizão. Ademais, a pergunta elaborada pelo autor assume que um governo minoritário pode ser destituído pela maioria parlamentar, desconsiderando que a oposição, embora majoritária, pode não possuir unidade para formar um governo alternativo. Além da influência exercida pelos distributivistas no que diz respeito à relação entre oposição e comissões, é possível conjecturar outra, provinda de Sartori.

A distinção entre política visível e política invisível proposta por Sartori (1976) pode explicar o motivo pelo qual Strøm (1990) viu nas comissões um lugar propício para a atuação da oposição. A colaboração entre governo e oposição é capaz de comprometer a imagem que os partidos constroem frente ao eleitor, tanto porque pode ser entendida como uma "traição" dos valores partidários, quanto porque há a possibilidade de comprometer a diferenciação entre as agremiações políticas, em ambos os casos, a punição é dada na forma de perda de votos. Desse modo, há incentivos para que acordos entre governo e oposição façam parte da política invisível, e ocorram fora do alcance dos olhares do público, nas comissões. Na Itália, por exemplo, a promoção de negociações entre o Partido Comunista Italiano (PCI), maior partido oposicionista, e o Partido Democrático Cristão (PDC) no interior das comissões permanentes, a portas fechadas, era a norma (DELLA SALA, 1993). Portanto, dada a construção feita pelos distributivistas e a diferenciação promovida por Sartori, podemos compreender o motivo pelo qual Strøm (1990) defendeu ser a comissão o lugar privilegiado para a atuação da oposição. A realidade dos fatos, todavia, contradiz o autor.

A leitura de Martin e Vanberg (2005; 2011), sobre o processo de alteração das propostas provindas do Executivo no Legislativo, permite que concluamos: ainda que presentes todas as características elencadas por Strøm (1990) para a ocorrência de um parlamento atuante e no qual a oposição tenha real capacidade de intervenção, é a coalizão a protagonista do espetáculo. Analisando as alterações aos projetos de lei originados pelo Executivo na Alemanha e na Holanda, Martin e Vanberg (2005) indicam que as propostas encabeçadas pela coalizão em desacordo com as preferências dos partidos oposicionistas não recebem mais alterações em comparação com as demais, achado que leva os autores a concluírem o que se segue: 
This null finding is at odds with much of the conventional wisdom in comparative research that portrays legislatures in these "consensus" systems as arenas in which opposition parties can exert real influence in policymaking. If opposition parties in fact have the power to influence policy in meaningful ways, then we should expect to see them use it to a greater degree on those policy proposals that are presumed to deviate more widely from their preferred policy outcomes (MARTIN \& VANBERG, 2005:102).

Vale ressaltar que os dados levantados pelos autores provém da Alemanha e da Holanda, ambos considerados países que facilitam a influência da oposição, conforme Powell (2000: 34). Ademais, em livro publicado em 2011 os autores expandem sua amostra de países, que passa a contar também com a Dinamarca, a França e a Irlanda. A conclusão permanece a mesma: não obstante países equipados com comissões consideradas fortes, nos termos de Strøm (1990), - Alemanha, Holanda e Dinamarca favoreçam o escrutínio das propostas encabeçadas pelo Executivo, a oposição não parece tirar qualquer vantagem do vigor das comissões. A conclusão parece ser válida também para o caso chileno. Toro-Maureira e Hurtado (2016) demonstram que também no Chile, apesar da presença de uma estrutura de comissões forte em termos comparativos (MARTIN, 2011) a oposição tem menores chances de assistir suas propostas de modificação aos projetos de lei serem aprovadas em comissões, em comparação com os membros da coalizão.

Não há dúvidas de que uma estrutura de comissões tal qual descrita por Strøm (1990) é essencial para munir o Legislativo, todavia, ainda que a distribuição de cargos seja proporcional, não há garantias de que a oposição se sairá bem-sucedida. Isso porque, como será argumentado no decorrer deste capítulo, a sorte da oposição depende sobretudo de seu peso numérico e do caráter do projeto de lei em discussão, se prioritário à maioria ou não. Em outras palavras, os fatores apresentados por Strøm (1990) informam sobre a capacidade de intervenção do Legislativo, mas não sobre o da oposição. O princípio majoritário é incontornável, o que significa dizer que, sem a anuência da maioria em plenário, o status quo legislativo não pode ser modificado. Desse modo, mesmo que o Congresso esteja equipado com comissões dotadas de capacidades institucionais, e que a oposição possua cargos relevantes no interior das mesmas, ao fim e ao cabo, todas as decisões apontam para o plenário, e os membros da oposição estão cientes disso. Parlamentares oposicionistas se defrontam com o dilema 
de terem de moderar suas propostas se quiserem vê-las aprovadas, ou se abster de participar.

A discrepância entre o outcome previsto por Strøm (1990) e a realidade dos fatos tal qual apresentada por Martin e Vanberg $(2005$; 2011) e Toro-Maureira e Hurtado (2016), insisto, é explicada pela imprecisão daquele ao utilizar o termo oposição, sem distingui-lo do termo minoria. Strøm (1990) argumenta que a existência de uma estrutura de comissões forte, força essa entendida como capacidade de afetar legislação, cujas posições-chave sejam distribuídas proporcionalmente entre os partidos com representação no Legislativo, criaria um ambiente no qual a produção de policies prescindiria de cargos no Executivo, dito de outro modo, as legendas não precisariam fazer parte da coalizão de governo para produzir políticas públicas. Por esse motivo, comissões fortes estariam associadas a governos minoritários - uma vez ser possível afetar o status quo via Legislativo, os partidos teriam menores incentivos para aderir à coalizão. A seta causal do argumento, portanto, segue a seguinte trajetória: a presença de comissões fortes concederia poder à oposição e, assim, estimularia a ocorrência de governos minoritários.

A desconsideração do princípio majoritário, grande contribuição de Krehbiel (1991), todavia, fez com que Strøm (1990) invertesse a ordem causal dos fatores, erro que custou-lhe a exatidão de suas previsões. Se toda e qualquer decisão deve ser aprovada pela maioria, ou a maioria pode assim exigi-lo, não é plausível supor que a oposição, se minoritária, conseguirá impor suas vontades ao plenário, mesmo que possua cargos importantes nas comissões. Entretanto, se a coalizão governista for minoritária, a oposição, entendida como as legendas não participantes da coalizão, estará em situação de maioria, tornando-se hábil a aprovar legislação. Ainda, a base governista, carente de apoio, precisará se aliar a setores oposicionistas se quiser assistir suas políticas implementadas. A incorporação do princípio majoritário à análise tem por efeito inverter a relação causal apresentada por Strøm (1990): governos minoritários criam a oportunidade para que a oposição se torne atuante, e não o contrário. Por conseguinte, a estrutura de comissões se torna irrelevante para explicar a força da oposição frente à dos demais partidos no Legislativo. Em conclusão, se a oposição for minoritária, as comissões não serão capazes de salvá-la, e se majoritária, não precisarão fazê-lo - não obstante comissões auxiliem na produção de legislação, a maioria depende apenas do plenário para aprová-las. 
A perspectiva informacional é persuasiva em defender que o princípio majoritário deve ser levado em consideração para a compreensão do funcionamento de Legislativos. No modelo de Krehbiel (1991) as comissões são importantes, não por serem capazes de subverter a vontade do plenário, mas por sua capacidade de prover informação e, assim, reduzir a incerteza inerente à produção de políticas. O autor está certo ao afirmar que comissões respondem à maioria, mas escorrega ao não considerar o elemento partidário para a constituição da maioria parlamentar (COX \& McCUBBINS, 1993). Seja para o caso americano ou para o caso brasileiro, regras e procedimentos que regem os trabalhos legislativos garantem poderes a alguns sujeitos que não são concedidos aos demais, com efeito, o controle sobre a agenda legislativa não é exercido por qualquer maioria, mas por uma maioria com nome próprio, que atende por Democratic ou por Republican (ROHDE, 1991; ALDRICH, 1995; COX \& McCUBBINS, 1993, 1995), que possui representação na Mesa Diretora e no Colégio de Líderes (FIGUEIREDO \& LIMONGI, 1999). É verdade que maiorias podem alterar as regras que garantem aos partidos a primazia sobre a agenda, mas o fato de não o fazerem se deve menos a um possível estado de equilíbrio do que à dificuldade inerente de se alterar regras quando outras estão em vigor (BINDER, 1997).

Nas partes subsequentes deste capítulo discuto três questões. Primeiro, o papel que desempenha a estrutura de comissões no que diz respeito à capacidade do Legislativo frente ao Executivo, uma vez que, sem um Congresso atuante, a oposição legislativa estaria por completo impedida de afetar o processo decisório. Segundo, a relação entre descentralização versus centralização no Brasil, explorando como esses dois elementos podem coexistir e quais são seus efeitos esperados, notadamente no que diz respeito à relação entre coalizão e oposição. Terceiro, a necessidade de admitirmos que o poder de influência da oposição não é determinado pela força das comissões, mas sim por sua capacidade de aliar-se à maioria. A seção empírica, ao final, está dividida em duas partes. Na primeira exponho a base de dados e as hipóteses a serem verificadas. Na segunda, apresento os resultados obtidos. Por fim, o capítulo é concluído.

\subsection{Relação entre descentralização e capacidades do Legislativo}

Comumente considera-se descentralizado um sistema que: i. divida competências e ii. permita a tomada de decisão por subconjuntos extraídos do total. A estrutura de comissões corporificaria, portanto, um modelo descentralizado de escolha entre políticas. É vasta a literatura que atribui às comissões papel fundamental na 
medida em que permitem ao Legislativo ação independente em relação ao Executivo (MEZEY, 1983; ARTER, 2006; SAIEGH, 2010).

Para que a oposição exerça influência no Legislativo é primeiro necessário que o Congresso seja atuante e não apenas um carimbador das propostas provindas do Executivo e, para ser um ator relevante, precisa possuir uma estrutura que permita a não cooptação. Argumentarei que, para que o Legislativo se torne uma arena relevante, apenas a divisão de competências é expediente necessário, em outras palavras, a possibilidade de tomada de decisão unilateral por parte das comissões é em princípio equivocada e, no limite, dispensável.

Em concordância com vasta literatura, reitero que as comissões possuem papel importante no que diz respeito à produção de informação. Strøm (1990) indica e Powell (2000) insiste que um número de comissões suficientemente elevado, com áreas de especialização bem delimitadas e que correspondam aos ministérios, além de restrições ao número de comissões em que cada parlamentar pode servir, são aspectos importantes para garantir que o Legislativo tenha condições de intervir no processo decisório.

Os elementos citados pelos autores seguramente informam sobre a capacidade do Legislativo de produzir conhecimento especializado sobre políticas públicas e, assim, não ficar restrito àquilo informado pelo gabinete. A dificuldade surge quando a descentralização é confundida com a noção de decisões sendo tomadas por minorias, interpretação que deu origem a famosos modelos sobre o Congresso americano, como o little government, por exemplo (LOWI, 1979; DAVIDSON, 1981).

Como será demonstrado na seção empírica, as comissões são muito importantes no processo de escrutínio das propostas originadas pelo Executivo, o mesmo é verdadeiro para outras matérias inequivocamente relevantes - refiro-me às Propostas de Emenda à Constituição (PEC). Desse modo, embora as comissões não possam tomar decisões à revelia da maioria, isso não faz com que percam sua importância, ou que não sirvam a contento como órgãos deliberativos. Não se trata, portanto, de apontar a fraqueza das comissões, mas de demonstrar que elas servem a outros propósitos que não o exercício de poder pela oposição. Pelo contrário, são utilizadas pela maioria como locus decisório importante.

\subsection{O caso brasileiro: descentralização e centralização}

Conforme reiterado, a descentralização do processo decisório se confunde com a estrutura de comissões; avaliemos o caso brasileiro. A Câmara dos Deputados possui 
vinte e três comissões permanentes, com áreas de jurisdição definidas e afinadas com as temáticas ministeriais. O Senado Federal, por sua vez, possui onze comissões permanentes, com áreas de jurisdição bem estabelecidas e, não obstante seu menor número, também com estreita relação com os temas dos ministérios. As comissões podem iniciar legislação, emendar os projetos e necessariamente apreciam as matérias ainda que na ocorrência de poder de urgência, o relator da comissão é chamado a dar seu parecer em plenário em favor da aprovação ou rejeição da proposta. Se considerados exclusivamente os elementos mencionados, a leitura de Strøm (1990) e Powell (2000) nos levaria a esperar comissões fortes, um ambiente institucional propício à atuação parlamentar, entretanto, não foi essa a interpretação aqui auferida.

Em via oposta, houve o desenvolvimento de uma interpretação que, apontando para a centralização do processo decisório brasileiro, esvaziou quase que por completo o papel das comissões (FIGUEIREDO \& LIMONGI, 1999). Aqui, as comissões seriam atrofiadas, não desempenhariam a contento nenhuma das funções a elas atribuídas pelas grandes teorias da ciência política: não facilitariam os ganhos de troca, tal qual previsto pelo modelo distributivista; não seriam devidamente informativas, para o incômodo dos adeptos à teoria informacional; e tampouco seriam utilizadas pelo partido majoritário ou coalizão de governo para imprimir sua preferência, que optariam por jogar o jogo diretamente no plenário. A centralização do processo decisório no Poder Executivo e nos líderes partidários teria como resultado um esvaziamento do papel das comissões no processo legislativo brasileiro.

No Brasil, a composição das comissões é estabelecida pelas lideranças partidárias e não há qualquer compromisso quanto à estabilidade dos indicados para as mesmas. Parlamentares podem ser transferidos para outras comissões a qualquer momento, se assim desejarem seus líderes partidários. Sem que a escolha para a comissão de interesse seja determinada pelo parlamentar e, em caso de sucesso, sem que esta seja assegurada pelo compromisso de permanência, impede-se que seja colocada em marcha a lógica do logrolling, visto que, sem estabilidade, os acordos de troca deixam de ser críveis. A alta rotatividade nas comissões seria prejudicial também à sua capacidade informacional, ao minar os incentivos para a especialização. Sem poder prever seu destino, pareceria ao parlamentar muito alto o custo de adquirir informação sobre determinada temática a cada nova rotação.

Ainda que os parlamentares, no relativo pouco tempo que permanecem em uma mesma comissão, superassem a falta de incentivo proveniente da ausência de qualquer 
regra que garanta a estabilidade como, por exemplo, a regra da senioridade, e buscassem se informar sobre a temática sob sua jurisdição, de fato conseguiriam impor sua preferência? Mais uma vez, a resposta é negativa. As comissões brasileiras não possuem poder negativo, ou seja, não são capazes de "engavetar" propostas. Se assim desejar a maioria, um pedido de urgência pode ser elaborado e o projeto em deliberação na comissão é encaminhado para apreciação em plenário. A possibilidade de retirar um projeto das comissões temáticas e encaminhá-lo diretamente ao crivo do plenário via a aprovação de um pedido de urgência foi encarada como a causa da fraqueza institucional das comissões. Isso porque impede que a comissão engavete projetos distantes de sua preferência e, como mais um agravante, retira o tempo necessário para a apreciação da matéria, que passa a ser discutida unicamente em plenário, às pressas.

Decidir sobre a proposta em plenário, inclusive nele formatando-a via emendas, enfraqueceria a comissão por pelo menos mais um motivo: ela perde sua capacidade de atuar estrategicamente. Assumindo um jogo no qual os atores podem prever o comportamento uns dos outros, imaginemos uma situação em que a preferência da comissão difira da presente em plenário. A comissão possui preferência pelo projeto por ela emendado ao status quo, mas opta pelo status quo frente à preferência do plenário. O plenário, por sua vez, prefere o projeto emendado pela comissão ao status quo, embora tenha em maior conta um projeto emendado por si próprio. Sem a possibilidade de impedir que seu projeto sofra alterações em plenário, por meio do expediente da closed rule, o trabalho realizado no interior da comissão passa a ser inútil, recaindo sobre o plenário o poder decidir sobre o projeto. Nesse caso, a ausência da closed rule direciona o projeto à opção menos preferida pela comissão, situação que, na sua presença, seria drasticamente diferente, e encaminharia o projeto à primeira opção da comissão.

A urgência legislativa, portanto, tolheria a capacidade da comissão em dois momentos: impediria que ela engavetasse projetos distantes de sua preferência; e limitaria o tempo hábil para a análise das propostas. Ademais, como mais um complicador, ainda que a comissão conseguisse emendar o projeto aproximando-o à sua preferência no pouco tempo que dispõe, não raro a ação seria desfeita em plenário e, portanto, seria sem propósito. Ademais, mesmo o poder positivo da comissão seria por aqui diminuto: sem um mecanismo que impeça o emendamento em plenário, coloca-se em risco o trabalho realizado no interior da comissão, situação que serviria como mais um desincentivo à atividade parlamentar no interior da mesma. Em conclusão, a 
competência da comissão para julgar e aprimorar as propostas seria solapado, recaindo sobre o plenário o protagonismo no tocante à conformação e deliberação dos projetos.

Fica evidente que o argumento em favor da fragilidade das comissões brasileiras se constrói a partir da negativa. Sem a regra de senioridade, sem poder negativo e debilitada em seu poder positivo, à comissão no Brasil faltariam todos os instrumentos capazes de torná-la atuante. Aos adeptos da teoria distributiva, as emendas ao orçamento vieram ao resgate e serviram como peça chave para explicar o funcionamento do Congresso brasileiro: sem um sistema de comissões capaz de munir o parlamentar com os meios necessários para ofertar as políticas caras ao seu eleitorado, emendar o orçamento surge como a maneira mais eficaz para fazê-lo (PEREIRA \& RENNÓ, 2001; AMES, 2003; PEREIRA \& MUELLER, 2003). Para os defensores da perspectiva partidária, o controle do sistema político pela coalizão governista se faz na contramão das comissões, via centralização do processo decisório no Executivo e nos líderes partidários: o controle do plenário é suficiente para a obtenção das vitórias da base (FIGUEIREDO \& LIMONGI, 1999). A abordagem informacional sobre o Legislativo brasileiro buscou demonstrar que as comissões brasileiras respondem à necessidade de produção de informação, mas os achados em favor dessa interpretação são ainda limitados (SANTOS \& ALMEIDA, 2005; ALMEIDA \& SANTOS, 2009).

Entretanto, se tomadas exclusivamente as características da estrutura de comissões brasileira, esta tende a ser considerada institucionalmente forte. De acordo com Saiegh (2010), em comparação com outros países da América Latina, o Legislativo brasileiro é provido de capacidades institucionais importantes, que o permite formatar as políticas públicas em nível mais elevado que seus vizinhos. Ainda assim, quando analisado especificamente o caso brasileiro, a centralização do processo decisório é apontada como capaz de anular quase que por completo o poder das comissões. É objetivo deste trabalho requalificar ambas as interpretações, demonstrando que a interação entre descentralização e centralização produz um sistema de comissões que, embora regido pelo princípio majoritário, não deixa de ser significativo, embora conduzido por uma maioria, não o é por qualquer maioria, mas por uma maioria organizada em termos partidários.

Dado que o processo decisório é centralizado e a pauta decidida pelos líderes, as comissões no Brasil não possuem condições institucionais para funcionarem tal qual os distributivistas diziam ser a norma para os Estados Unidos (FIGUEIREDO \& LIMONGI, 1999). Entretanto, embora incapazes de solapar a vontade da maioria, são o 
lugar no qual o acordo no seio da maioria ganha corpo. Não obstante a falta de instrumentos institucionais para o controle da produção de políticas, em comparação com aqueles presentes no modelo americano, demonstrar-se-á que as comissões brasileiras desempenham função fundamental no que diz respeito à conformação de preferências. São nelas que os projetos recebem as modificações necessárias para que uma maioria seja reunida em torno da proposta, sem a qual sua aprovação não seria possível (FREITAS, 2016). Defende-se que, para que uma estrutura de comissões seja considerada relevante, conferir poder à oposição ou a minorias não é condição sine qua non, mas sim permitir a produção de informação e o alcance de acordos pela maioria.

\subsection{Se não nas comissões, onde? O lugar da oposição}

Como argumentado, a estrutura de comissões faz parte do arranjo institucional democrático e, portanto, não escapa ao princípio majoritário. Se as comissões não oferecem vantagens à oposição em relação ao plenário, qual das duas arenas melhor servirá os interesses daqueles não pertencentes à coalizão? Argumento que o plenário, na contramão das previsões da literatura, possui vantagens até então desconsideradas. Ao formar uma coalizão, os partidos integrantes selam um acordo que envolve o comprometimento em relação a uma agenda de políticas (LAVER \& SCHOFIELD, 1991). Se a coalizão é majoritária, é de se esperar que as políticas produzidas pelo Executivo necessariamente incorporem as preferências dos parceiros da coalizão e apenas acidentalmente às da oposição. É preciso lembrar que fazer parte de uma coalizão possui custos (STRØM, 1990), que precisam ser compensados com benefícios para que, ao final, o saldo seja positivo. Possuir precedência em relação aos membros da oposição no momento da feitura de políticas pode ser encarado como um deles. As comissões iniciam o processo de avaliação das propostas e, embora a conciliação de interesses possa preceder a apresentação do projeto ao Congresso (THIES, 2001), a passagem da matéria pelo Legislativo oferece condições privilegiadas para a conformação de preferências entre os membros da coalizão (MARTIN \& VANBERG, 2005, 2011; FREITAS, 2016). A comissão, sobretudo o relator governista, é peça-chave no processo de alteração, tornando o papel da oposição diminuto (FREITAS, 2016). É plausível supor que a coalizão buscará o acordo primeiro em seu seio, nas comissões, e somente depois, se houver necessidade e ganhos, procurará incorporar as demandas da oposição. Desse modo, do ponto de vista da base governista, faz sentido cimentar o 
acordo no interior da base antes, ainda nas comissões, e manter a oposição afastada, caso suas preferências distem daquelas presentes na coalizão, durante essa etapa.

Sob a ótica da oposição, esperar por uma oportunidade em plenário também parece uma escolha acertada. A incerteza é inerente a todo e qualquer Legislativo, tornando impossível aos atores saberem sem sombra de dúvidas qual será o desfecho da tramitação de um projeto. Se o status da coalizão é majoritário, a oposição sabe que, nominalmente, não é necessária para a aprovação de qualquer projeto apresentado pelo Executivo e, assim, possui reduzidos poderes de barganha no processo de alteração. Contudo, uma maioria nominal não necessariamente se refletirá em maioria factual, visto que a ausência de acordo entre os partidos governistas, e/ou a ocorrência de indisciplina partidária no interior de uma ou mais legendas da coalizão podem fazer com que os votos necessários não sejam oferecidos.

Assume-se que quanto mais próximo no tempo está a votação final da matéria, mais aptos estão os parlamentares a auferir se o projeto contará com o apoio necessário para a sua aprovação em plenário ou não. Uma vez que o plenário é a última etapa do processo de tramitação, a incerteza nesse estágio é reduzida, situação que fornece à oposição melhores condições de julgar seu poder de barganha e, se o for suficientemente elevado, obter concessões do governo em troca de apoio em plenário. $\mathrm{O}$ mecanismo é o mesmo nas comissões, embora em sentido contrário: sem ser capaz de julgar se a coalizão majoritária irá perder sua coesão, o ato de propor alterações no interior da comissão é ineficiente, dado que em muitos casos o parlamentar oposicionista incorrerá no custo de propor a modificação, ainda que por diversas vezes com poucas chances de assisti-la aprovada. Por parte da oposição, portanto, a ação na comissão se torna menos atrativa em razão do cálculo baseado no princípio da antecipação ${ }^{6}$. Se para a coalizão é mais vantajoso fechar o diálogo em seu seio quando o projeto está ainda nas comissões, para a oposição a antecipação desse comportamento por parte daquela pode inibir a ação nesse estágio do processo. Ademais, no plenário a visibilidade é muito maior do que no interior das comissões temáticas. A oposição pode fazer uso do plenário para constranger a coalizão e forçá-la a modificar trechos sensíveis ao eleitorado.

\footnotetext{
${ }^{6}$ Uma vez definido o relator, assumo que este passar a ser o principal ator da comissão. Conforme gráfico 7, o relator oposicionista opera regido pela lógica da antecipação: tende a não apresentar substitutivos. Parlamentares oposicionistas, contudo, apresentam emendas nas comissões, ainda que com pouca chance de sucesso. Isso pode acontecer por diversos motivos, dentre os quais o baixo custo de apresentação de uma emenda (em comparação a um substitutivo) e à necessidade de "mostrar serviço" a eleitores e grupos de interesse.
} 
Em que pese a precedência da coalizão no processo feitura de políticas, a influência da oposição sobre as políticas não está estritamente condicionada à necessidade da coalizão de adquirir mais votos, e esse fato nada tem a ver com o suposto poder das comissões de criar desvios antimajoritários. Dito de outro modo, a oposição pode intervir ainda que seus votos sejam dispensáveis para a aprovação da matéria. Diferentemente do que indicou Riker (1962) e as teorias sobre cartelização do legislativo, o jogo não é necessariamente de soma zero e a coalizão governista não tem interesse em controlar absolutamente toda e qualquer matéria (ALDRICH \& ROHDE, 2000). A depender da homogeneidade de preferências no interior da coalizão e da diferenciação entre governo e oposição, a coalizão terá maiores ou menores incentivos para intervir no processo e impedir a atuação da oposição. Em outras palavras, se governo e oposição não possuírem preferências distintas em relação ao projeto ou, ainda, se a própria coalizão não for capaz de chegar a um acordo sobre os termos da política, não há razão para esperarmos que a oposição será impedida de participar. Dentre todas as votações nominais ocorridas entre 1988 e 2014, 34,7\% (979 votações) se caracterizaram pela unanimidade, situação na qual $90 \%$ ou mais dos votos são iguais. Ou seja, em um contingente elevado de votações, o conflito coalizão versus oposição não é observado. Em conclusão, se o objetivo é analisar o comportamento da oposição e quais são as condições que favorecem ou dificultam sua ação, olhar para a estrutura de comissões é mirar no alvo errado.

\subsection{A base de dados}

Para verificar empiricamente as afirmações apresentadas em seções precedentes serão mobilizados dois conjuntos de dados, o primeiro sobre alterações feitas aos projetos em tramitação no Legislativo, e o segundo sobre a distribuição de cargos importantes nas comissões temáticas. A escolha pelas alterações se justifica por ser essa a principal maneira pela qual parlamentares exercem seu poder de legislar. Embora sistemas parlamentaristas sejam conhecidos por garantirem ao Executivo a dominância sobre a produção legal (LIJPHART, 1999), Martin e Vanberg (2005, 2011), analisando parlamentos europeus, atestam sobre a importância das alterações ocorridas no Legislativo para a produção legal nos países alvo de suas análises. Sobre o Brasil, sabemos que o Executivo é responsável por cerca de $80 \%$ das leis produzidas (FIGUEIREDO \& LIMONGI, 1999), não obstante, a participação dos parlamentares não está reduzida aos demais 20\%. Freitas (2013) demonstrou que deputados e 
senadores são responsáveis, em média, por $36 \%$ do conteúdo das leis originadas no Poder Executivo que sofreram vetos presidenciais. Olhar para as alterações promovidas por parlamentares é, portanto, olhar para uma de suas tarefas primordiais.

Com o objetivo de mensurar a contribuição da coalizão e da oposição no que diz respeito às alterações ocorridas no Legislativo, assim como determinar como prioritária as arenas em que atuam ambos os grupos - comissão ou plenário - o presente capítulo analisa todas as alterações realizadas aos projetos do Executivo aprovados entre os anos 1995 e 2014 que tenham sofrido vetos presidenciais, sejam eles parciais ou totais. Também foram analisadas todas as alterações realizadas às Propostas de Emenda à Constituição aprovadas em ao menos uma Casa entre 1995 e 2010, oriundas tanto do Executivo, quanto do Legislativo. Seguindo Couto e Arantes $(2009$, 2010) e Freitas (2016), a base de dados de alterações foi construída utilizando como unidade o dispositivo legal, que corresponde à menor unidade presente no texto da lei, porém que ainda possui significado legal completo.

Tal qual feito por Couto e Arantes $(2009 ; 2010)$ para o texto constitucional, os projetos de lei foram destrinchados em dispositivos, assim como todas as emendas e substitutivos, tornando possível verificar na íntegra os trechos modificados por deputados e senadores. O banco de dados conta com informação sobre a modificação e exclusão de dispositivos já presentes no projeto, assim como sobre a inclusão de dispositivos não previstos pelo projeto original. Ainda, a base informa sobre o autor de cada alteração e o local em que foi apresentada a emenda ou substitutivo, se no plenário ou na comissão, e se na Câmara dos Deputados ou no Senado Federal. Uma base de dados com essas características fornece precisão às análises, no entanto, exige que um recorte seja estabelecido. Freitas (2016) fez a escolha pelas matérias vetadas por representarem um possível conflito entre Executivo e Legislativo. Embora por motivo diferente, as matérias vetadas são também propícias para o estudo aqui desenvolvido, isso porque podem indicar os locais mais prováveis para a intervenção da oposição. As Propostas de Emenda à Constituição, por seu turno, são objeto oportuno por exigirem amplas maiorias para a sua aprovação, situação que facilitaria a observação da atuação da oposição.

A amostra conta com 327 projetos de lei destrinchados ao nível dos dispositivos, categorizados de acordo com suas especificidades de tramitação, são eles: Projetos de Lei (PL), Projetos de Lei Complementar (PLP), Medidas Provisórias (MPV) e Propostas de Emenda à Constituição (PEC). A esses projetos foram apresentadas e aprovadas 
17296 alterações, mensuradas por meio da análise dos dispositivos, conforme tabela abaixo.

Tabela 1 - Número de projetos analisados e dispositivos por categoria de projeto

\begin{tabular}{lrr}
\hline \hline Modalidade de Projeto & Número de Dispositivos Alterados & Número de Projetos \\
\hline MPV & 10290 & 161 \\
PEC & 1326 & 70 \\
PL & 3792 & 87 \\
PLP & 1888 & 9 \\
Total & 17296 & 327 \\
\hline \hline
\end{tabular}

Fonte: Banco de Dados Legislativos do Cebrap

Os dados recolhidos sobre as alterações aos projetos permitirão que verifiquemos se comissões brasileiras são desimportantes e não estão envolvidas no processo de modificação de propostas, recaindo sobre o plenário o papel de formatar as matérias. Também teremos condições de auferir se de fato as comissões se configuram como um ambiente mais propício à atuação da oposição, frente ao plenário. Por fim, poderemos observar em quais projetos a oposição concentra suas alterações e se tal concentração pode ser associada à ocorrência de governos minoritários e/ou ao fato de incidirem sobre propostas nas quais a polarização entre governo e oposição era fraca ou em matérias não presentes na agenda prioritária da coalizão.

Ainda, foram levantados dados sobre a distribuição de cargos relevantes nas comissões temáticas na Câmara e no Senado, de modo a verificar se a partilha de presidências, vice-presidências e as relatorias de projetos aprovados e todos aqueles apresentados pelo Executivo, segue o critério da proporcionalidade. Não há dúvidas de que a presidência de uma comissão é um cargo extremamente relevante. Dentre as várias prerrogativas do cargo, destaca-se o poder de indicar relatores. O relator, por sua vez, é responsável por informar seus pares sobre o impacto do projeto, podendo reescrevê-lo na forma de um substitutivo, instrumento este amplamente utilizado (FREITAS, 2016).

Os dados permitirão que avaliemos empiricamente a validade de diversas assertivas. Será verificado se as comissões brasileiras podem ser consideradas desimportantes, recaindo sobre o plenário o papel de formatação das propostas. Também será avaliada assertiva segundo a qual as comissões seriam o lugar mais propício à atuação oposicionista, em contraposição ao plenário. Por fim, será verificada a hipótese segundo a qual uma distribuição proporcional de cargos entre os partidos 
políticos levaria a uma maior capacidade de intervenção da oposição, entendida como todos os partidos não detentores de pastas ministeriais.

\subsection{Resultados}

A primeira conclusão que podemos tirar a partir da análise dos dados é que o processo de alteração acontece sobretudo nas comissões temáticas. Conforme tabela 2 , $90 \%$ das modificações ocorreu no interior das comissões, contra apenas $10 \%$ no plenário. Também salta aos olhos o predomínio da coalizão, responsável por cerca de $83 \%$ de todas as alterações. A coalizão altera em proporção muito superior à oposição em todas as modalidades de projeto.

Tabela 2 - Número percentual de alterações realizadas

\begin{tabular}{lrrrrrrrrl}
\hline \hline & \multicolumn{2}{c}{$P L$} & \multicolumn{2}{c}{ PLP } & \multicolumn{2}{c}{$M P V$} & \multicolumn{2}{c}{ PEC } \\
& Coalizão & Oposição & Coalizão & Oposição & Coalizão & Oposição & Coalizão & Oposição & Total \\
Plenário & $6,0 \%$ & $35,3 \%$ & $20,3 \%$ & $100,0 \%$ & $5,3 \%$ & $3,1 \%$ & $19,5 \%$ & $48,0 \%$ & $(1665)$ \\
Comissão & $94,0 \%$ & $64,7 \%$ & $79,7 \%$ & $0,0 \%$ & $94,7 \%$ & $96,9 \%$ & $80,5 \%$ & $52,0 \%$ & $(15631)$ \\
Total & $(3089)$ & $(703)$ & $(1862)$ & $(26)$ & $(8317)$ & $(1973)$ & $(1082)$ & $(244)$ & $(17296)$ \\
\hline \hline
\end{tabular}

Fonte: Banco de Dados Legislativos do Cebrap 
Gráfico 1 - Padrão de Alteração: Coalizão e Oposição

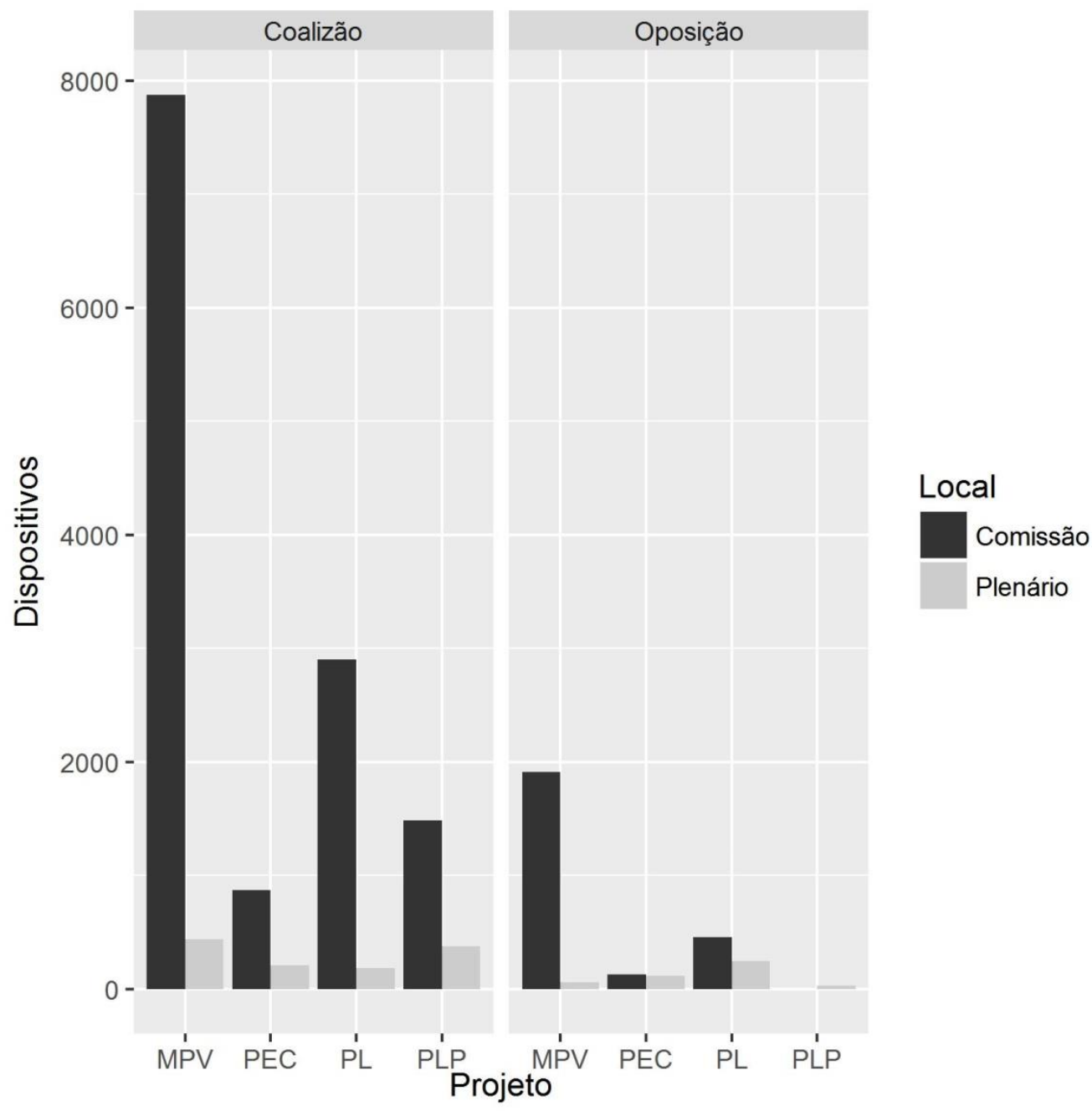

Fonte: Banco de Dados Legislativos do Cebrap

Se é verdade que comissões fortes - entendidas como aquelas detentoras das características descritas por Strøm (1990) - de fato conferem indistintamente poder à oposição, em contraposição ao plenário, deveríamos observar esta mais bem sucedida nesta arena do que em outras. Ainda, considerando a pouca importância atribuída por Figueiredo e Limongi (1999) às comissões, seria também de se esperar que a coalizão fizesse pouco uso dessa arena. Quando nos atemos ao local onde a modificação foi apresentada, notamos um padrão diferente entre membros da coalizão e da oposição em sentido oposto ao esperado por Strøm (1990). De acordo com o gráfico 2, são os parlamentares da base governista os responsáveis pelo maior número de alterações apresentadas e aprovadas no interior das comissões. A coalizão empreende $91 \%$ de suas modificações nas comissões, frente a apenas $9 \%$ em plenário ${ }^{7 .}$

\footnotetext{
${ }^{7}$ Para mais, ver Freitas (2016).
} 
Se os projetos são diferenciados por seu tipo, cada qual com regime de tramitação próprio, permanece evidente que a estratégia de alteração da coalizão passa pelas comissões: o percentual de modificações em comissão é sempre superior a $80 \%$. Sobre a oposição, parlamentares cujos partidos não pertencem à coalizão também alteram mais em comissão, entretanto, a vantagem é menor e, a depender do tipo de projeto, inexistente. Os padrões apresentados pela coalizão e pela oposição são, portanto, distintos, fato atestado por meio de um teste de proporções, conforme gráfico 3 - é possível verificar que a coalizão faz uso das comissões em percentual superior à oposição, diferença essa sempre estatisticamente significante, independentemente do tipo de projeto.

Gráfico 2 - Proporção de alterações realizadas em comissão e plenário

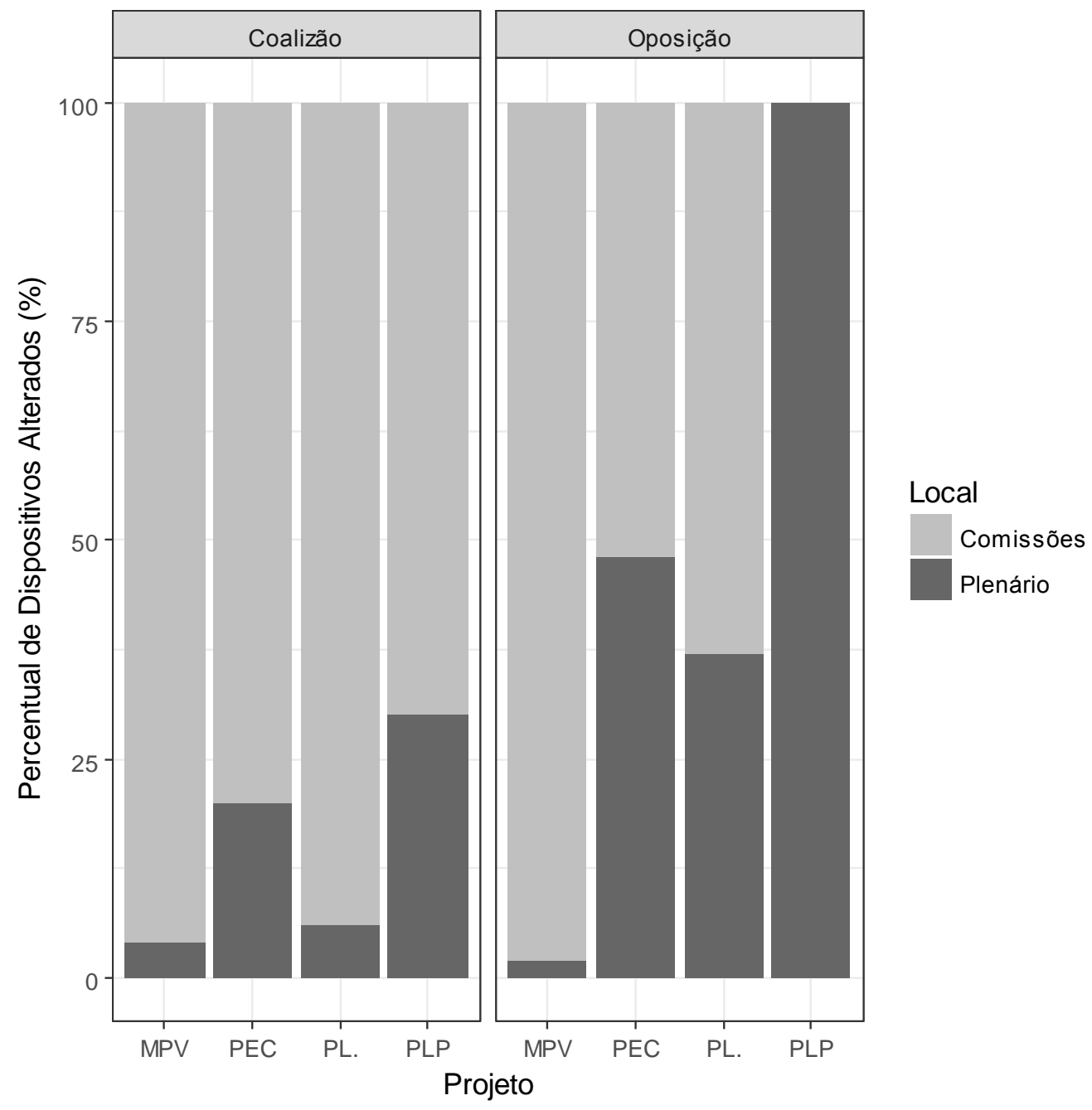

Fonte: Banco de Dados Legislativos do Cebrap 
Gráfico 3 - Proporção de Alterações Realizadas na Comissão: Coalizão e Oposição ${ }^{8}$

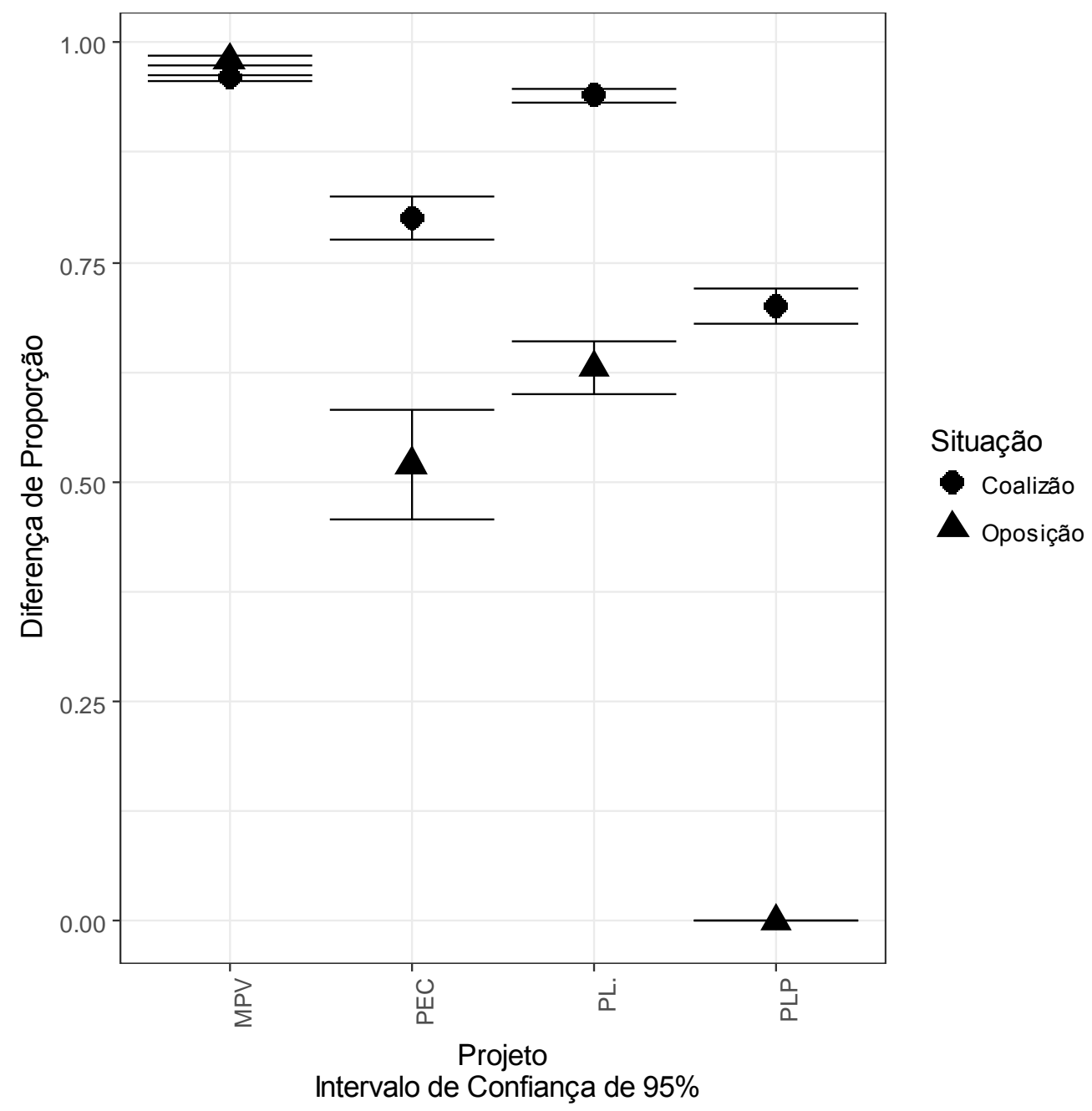

Fonte: Banco de Dados Legislativos do Cebrap

De acordo com a tabela 2, a despeito de ser a coalizão a responsável pela grande maioria das alterações, a oposição diminui a diferença em plenário. Em projetos de lei ordinária (PL), altera mais que a própria base de governo. Em Propostas de Emenda à Constituição (PEC) sua participação em plenário é também importante. Quando analisadas as modificações realizadas em comissão, o quadro se inverte: a coalizão domina o processo de alterações. Com exceção às Medidas Provisórias ${ }^{9}$, a oposição ganha pouco na comissão em relação ao plenário. Ainda, de acordo com o gráfico 3, a proporção de alterações realizadas no interior das comissões por governo e oposição demonstra que a diferença entre os grupos é significativa. As duas hipóteses levantadas

\footnotetext{
${ }^{8}$ Os intervalos de confiança foram construídos por meio da realização de um teste bivariado de diferença entre duas proporções, com $95 \%$ de confiança. Para todos os casos, o p-valor obtido foi 0,000 .

${ }^{9}$ As medidas provisórias possuem tramitação extraordinária e, embora as modificações aparentem ser de comissão, todas são apresentadas em um curto período de tempo, a uma comissão constituída para esse fim. Considerando o número total de modificação realizadas a MPVs, alterações em plenário são raras.
} 
na seção precedente, as quais previam que: i. as comissões seriam um local mais propício à atuação da oposição do que o plenário e que ii. a coalizão teria atuação predominante no plenário encontram pouco respaldo.

Tabela 3 - Número percentual de alterações realizadas por relator e parlamentar

\begin{tabular}{lrrrrrrrrr}
\hline \hline & \multicolumn{2}{c}{$P L$} & \multicolumn{2}{c}{$P L P$} & \multicolumn{3}{c}{$M P V$} & \multicolumn{3}{c}{ PEC } \\
& Coalizão & Oposição & Coalizão & Oposição & Coalizão & Oposição & Coalizão & Oposição & Total \\
Relator & $87,0 \%$ & $55,2 \%$ & $79,7 \%$ & $0,0 \%$ & $85,8 \%$ & $65,5 \%$ & $74,1 \%$ & $21,3 \%$ & $(13843)$ \\
Parlamentar & $13,0 \%$ & $44,8 \%$ & $20,3 \%$ & $96,2 \%$ & $14,0 \%$ & $33,5 \%$ & $10,7 \%$ & $50,0 \%$ & $(3181)$ \\
Lideranças & $0,0 \%$ & $0,0 \%$ & $0,0 \%$ & $3,8 \%$ & $0,2 \%$ & $1,0 \%$ & $15,2 \%$ & $28,7 \%$ & $(272)$ \\
Total & $(3089)$ & $(703)$ & $(1862)$ & $(26)$ & $(8317)$ & $(1973)$ & $(1082)$ & $(244)$ & $(17296)$ \\
\hline \hline
\end{tabular}

Fonte: Banco de Dados Legislativos do Cebrap

Gráfico 4 - Número de Alterações realizadas por relator e parlamentar por coalizão e oposição ${ }^{10}$

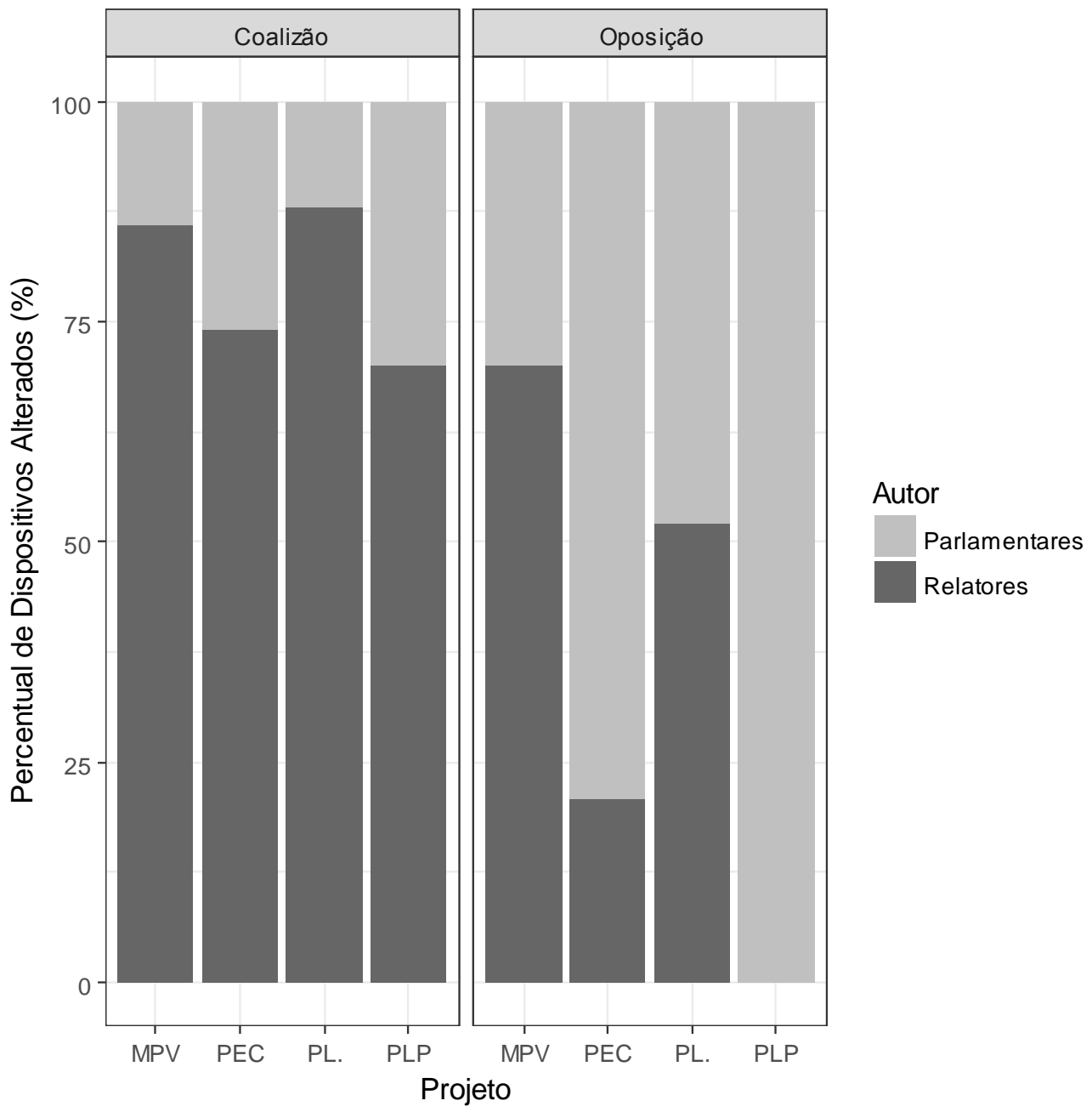

Fonte: Banco de Dados Legislativos do Cebrap

\footnotetext{
${ }^{10}$ As modificações realizadas pelas lideranças partidárias foram desconsideradas para a consecução deste gráfico.
} 
O gráfico 4 informa sobre as alterações empreendidas por relatores: $86 \%$ das modificações foram propostas por relatores da coalizão, contra apenas 14\% de relatores da oposição. É evidente que o relator é peça chave. Podemos conjecturar duas explicações possíveis para a pouca expressão dos relatores oposicionistas: I. os dados observados são resultado do pequeno número de relatorias de que dispõe a oposição partindo de uma perspectiva partidária, dado que os relatores são designados pelos presidentes das comissões, podemos supor ser possível que a coalizão controle a designação dos membros das comissões e, assim, controle também a eleição dos presidentes e, estes, por sua vez, restrinjam a nomeação da oposição às relatorias; II. relatores oposicionistas, prevendo a rejeição, deixam de apresentar modificações.

A primeira explicação mencionada é derivada de Strøm (1990) e Powell (2000), segundo os autores, apenas uma estrutura de comissões forte não é suficiente para garantir à oposição poder de influência, é necessário também que os parlamentares não pertencentes à base de governo possuam cargos relevantes no interior das committees, em proporção ao tamanho de suas bancadas. O reduzido impacto de relatores oposicionistas estaria associado ao seu menor número? Estaria a oposição recebendo menor número de presidências, vice-presidências e, por esse motivo, valor de relatorias inferior ao que seria esperado caso a proporcionalidade fosse atendida? A resposta é não. A oposição possui número considerável de presidências e vice-presidências, tanto na Câmara dos Deputados quanto no Senado Federal, inclusive, por vezes, em proporção superior ao tamanho de sua bancada. Desse modo, podemos afastar a suspeita de que a coalizão possuiria monopólio sobre os cargos nas comissões. 


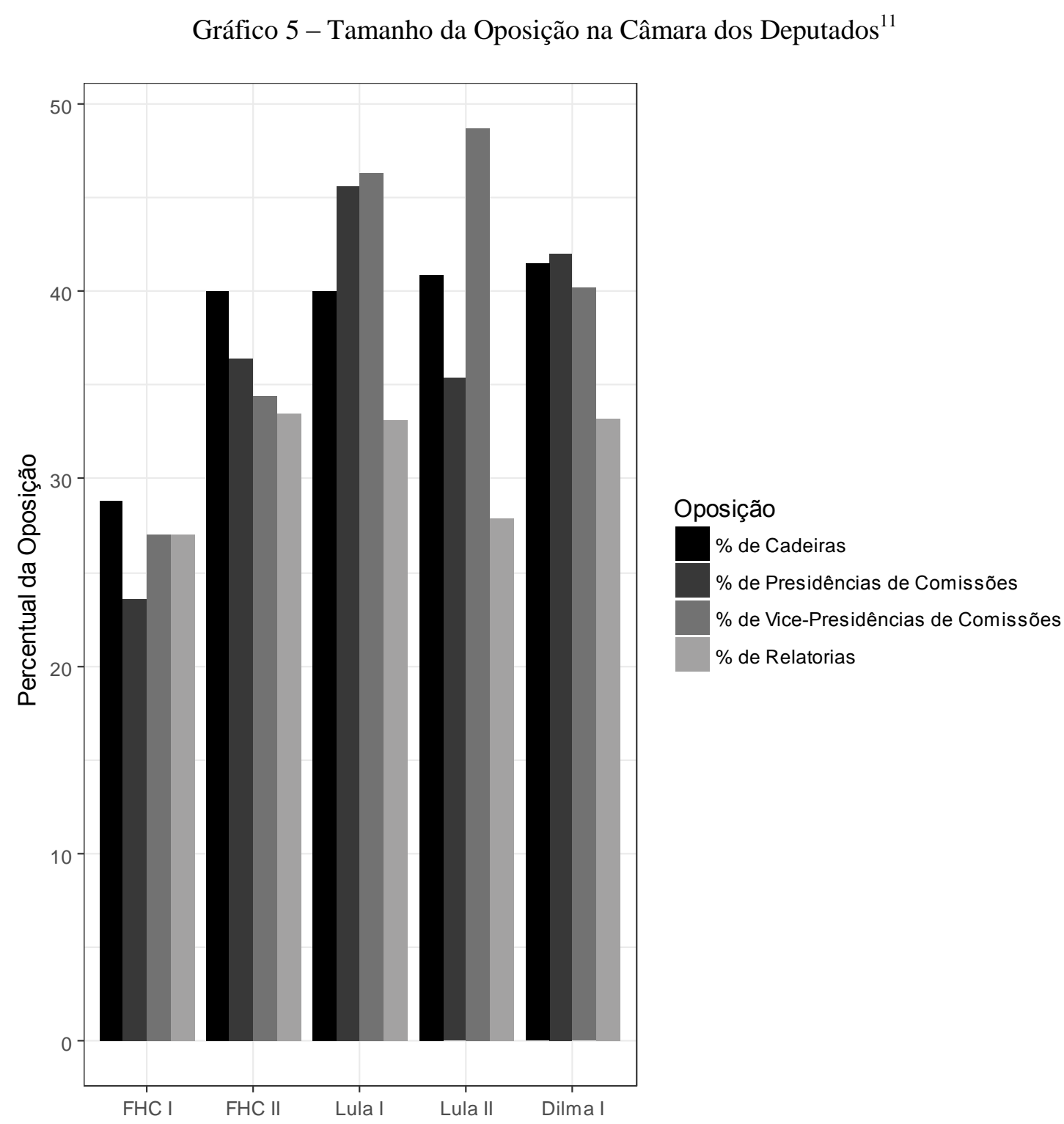

Fonte: Banco de Dados Legislativos do Cebrap

\footnotetext{
${ }^{11}$ Nos gráficos 5 e 6 o percentual de cadeiras da oposição foi calculado por meio de uma média ponderada, de modo a considerar o número de dias de cada uma das coalizões criadas durante o mandato presidencial. Por exemplo, no primeiro mandato de Fernando Henrique Cardoso duas coalizões foram formadas, a primeira contava com $60,2 \%$ das cadeiras na Câmara e durou 481 dias, a segunda contava com 76,6\% das cadeiras na Câmara e durou 980 dias. A média do período é obtida, desse modo, da seguinte maneira: $[(60,2 * 481)+(76,6 * 980)] / 1461$. O percentual de presidências de comissões informa a média, por ano, de presidências detidas por membros da oposição na data da nomeação. O mesmo critério é obedecido para estabelecer o percentual de vice-presidências e relatorias (foram consideradas as relatorias de todos os projetos aprovados e todos aqueles apresentados pelo Executivo, entre 1995 e 2014). Especificamente sobre o Senado, os presidentes e vice-presidentes são elegidos para um mandato de dois anos, e não de um ano, como na Câmara, desse modo, a média por presidente e vice-presidente foi feita considerando apenas dois anos, e não quatro.
} 
Gráfico 6 - Tamanho da Oposição no Senado Federal

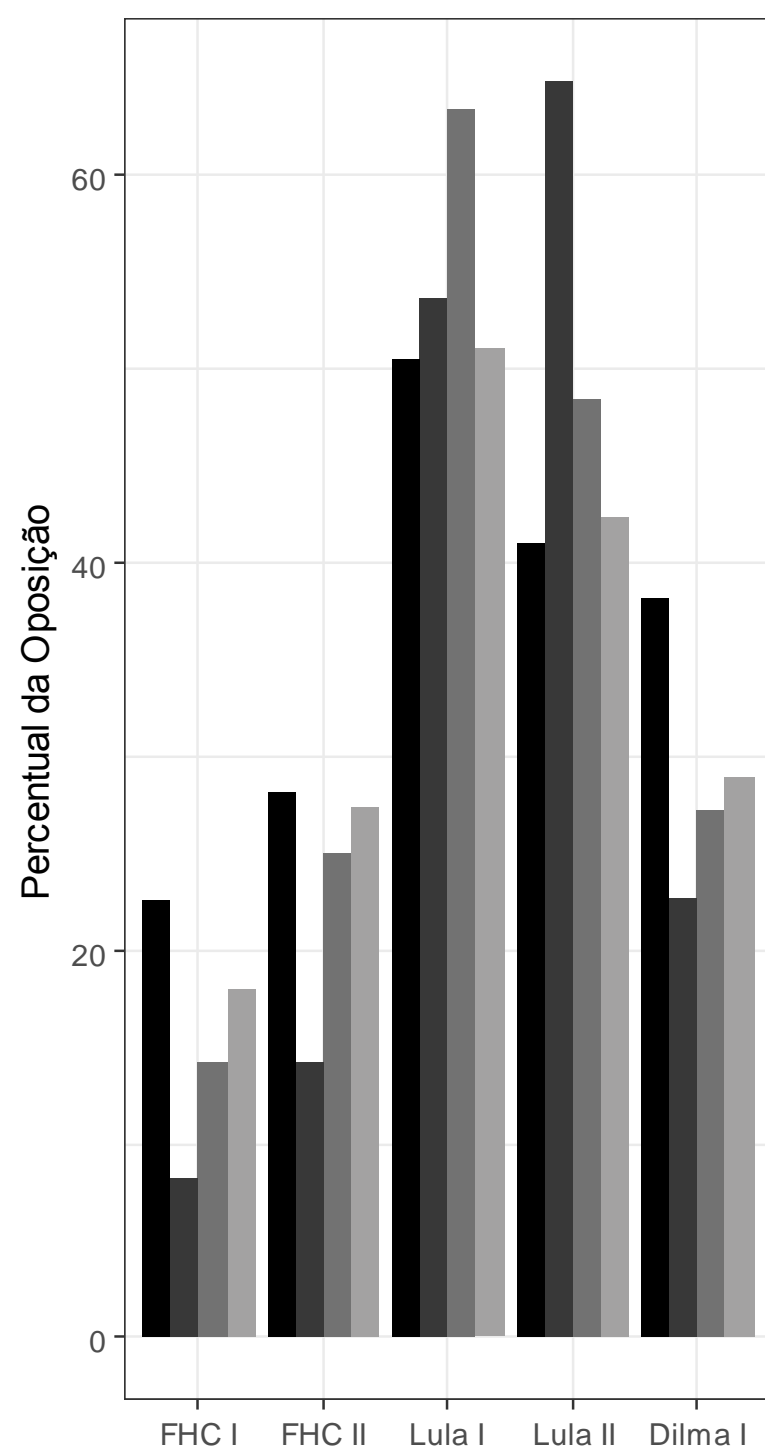

\section{Oposição}

$\%$ de Cadeiras

$\%$ de Presidências de Comissões

$\%$ de Vice-Presidências de Comissões

$\%$ de Relatorias

Fonte: Banco de Dados Legislativos do Cebrap

No gráfico 7, podemos observar o número de projetos com dispositivos que possuía ao menos um relator e, destes, quantos o relator de fato propôs modificação. É possível notar que, quando um projeto é relatado por relatores da coalizão, em $78 \%$ dos casos o relator governista tenta alterar o projeto. O mesmo não é verdadeiro para os relatores oposicionistas. Embora tenham relatado cerca de metade dos projetos presentes na amostra, em apenas 38\% destes casos propuseram alteração. Desse modo, a pouca relevância da oposição quando o assunto é alteração não pode ser explicada apenas pelo menor número de relatores de que dispõe. $\mathrm{O}$ relator oposicionista, quando ocupa a cadeira do relator, não sugere alterações. A atuação pouco expressiva dos relatores da oposição é resultado não da rejeição de suas sugestões, mas da própria 
ausência de proposta de modificação. A não ser que a oposição estivesse plenamente satisfeita com o projeto tal qual formatou a coalizão, a falta de iniciativa deve ser decorrência de um processo de antecipação: prevendo a derrota, relatores oposicionistas optam por não incorrer no custo de apresentar um substitutivo.

Gráfico 7 - Relação entre relatores e apresentação de substitutivo

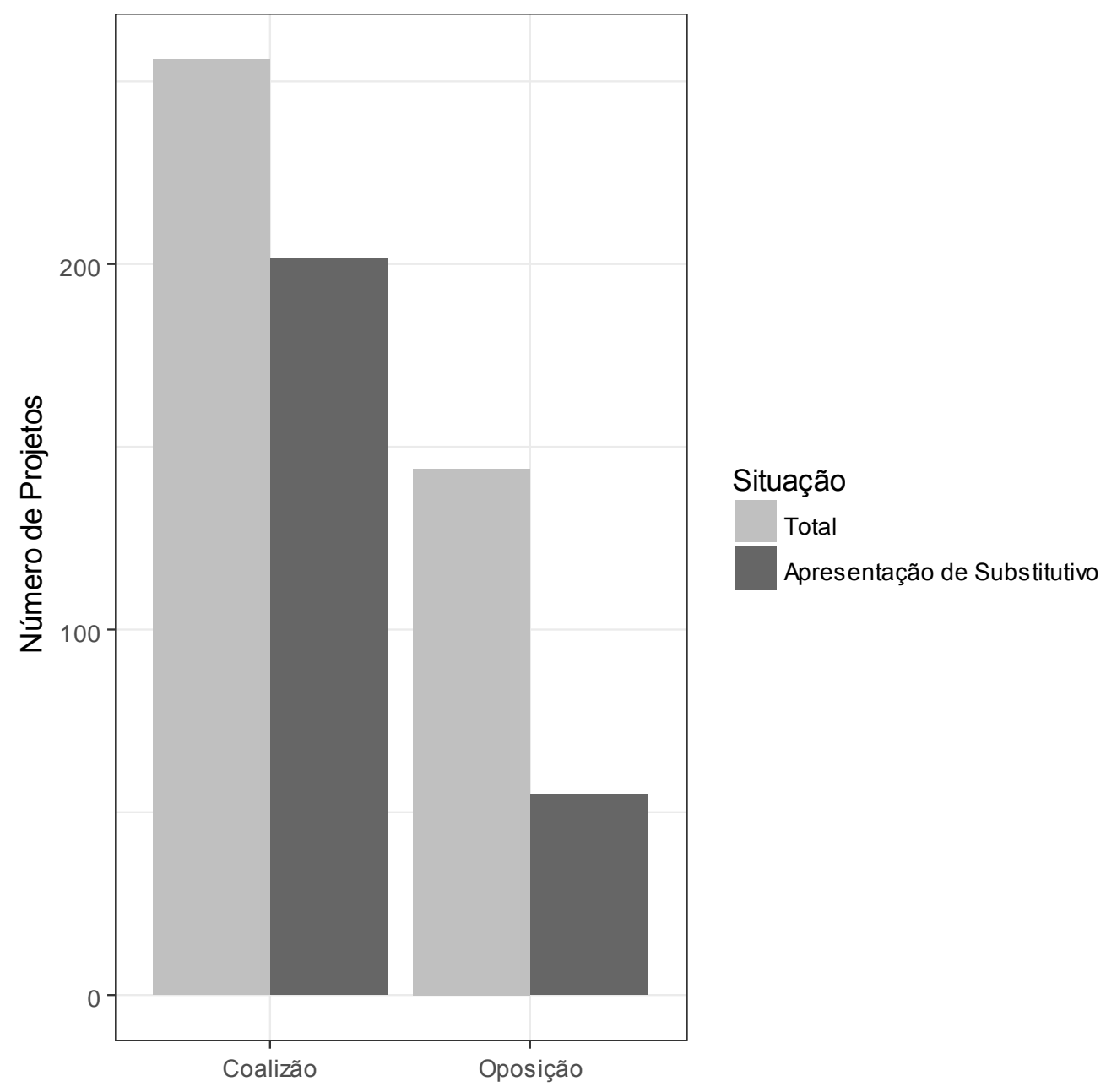

Fonte: Banco de Dados Legislativos do Cebrap

Em conclusão, não obstante sejam os relatores os atores principais quando o assunto é alteração, a baixa participação da oposição não se explica apenas por esta deter relatorias em menor número. Em outras palavras, possuir um cargo chave na comissão não é condição suficiente para que a oposição consiga alterar e, simetricamente, também não o deve ser para a coalizão. Argumento que o relator da coalizão possui vantagem em relação ao oposicionista porque conta com uma maioria, fazendo das alterações um meio de sedimentar esta maioria. 
Resta saber como se distribuem as alterações da oposição e se o padrão difere daquele apresentado pela coalizão. Parlamentares oposicionistas concentram suas alterações em alguns poucos projetos? Esses projetos são os mesmos em que a coalizão focaliza sua atividade? O gráfico abaixo é uma Curva de Lorenz. O objetivo é demonstrar que a grande maioria dos dispositivos alterados, tanto pela oposição, quanto pela coalizão, concentra-se em um número muito reduzido de projetos.

Gráfico 8 - Concentração de Dispositivos: Total

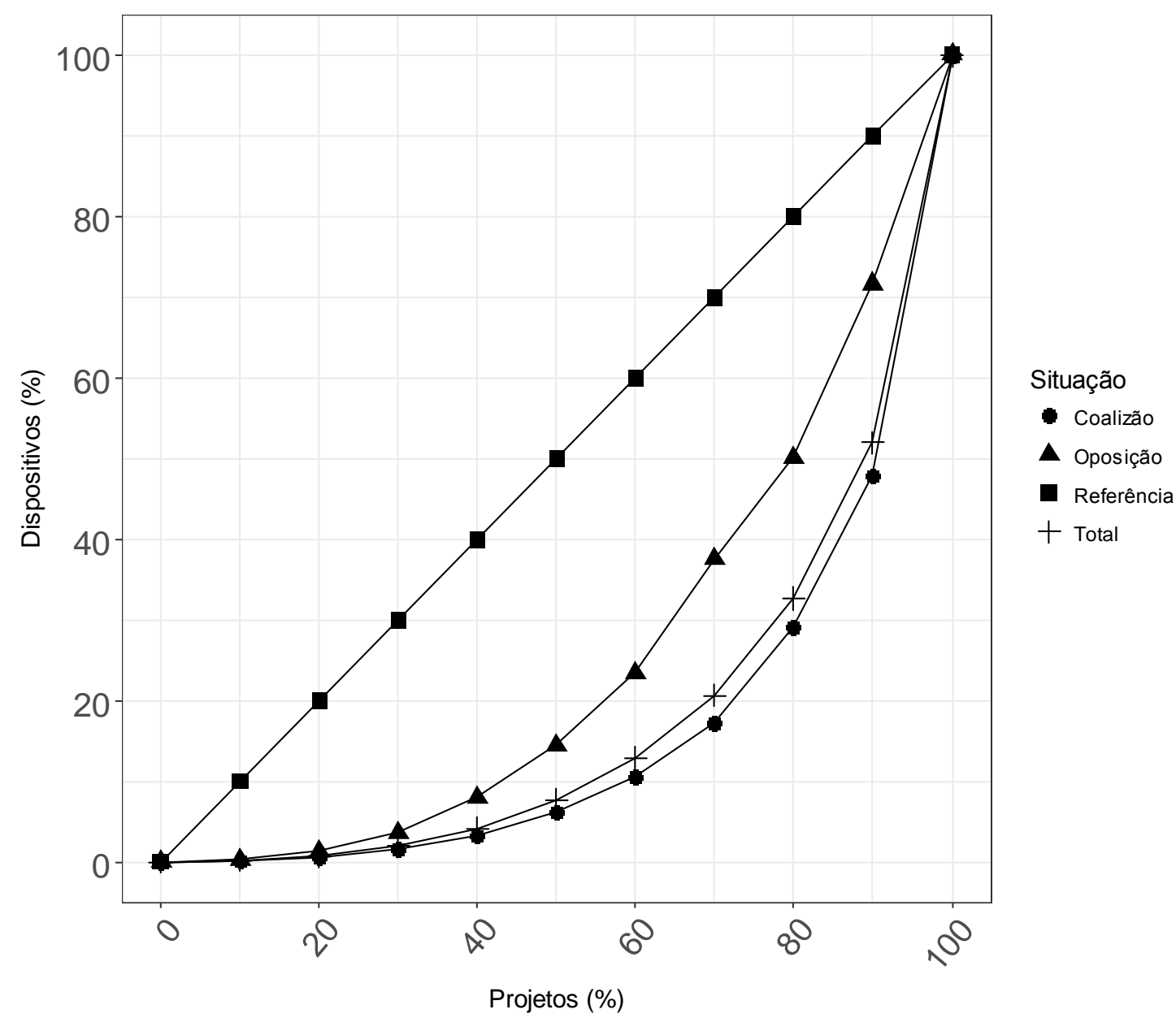

Fonte: Banco de Dados Legislativos do Cebrap

O gráfico 8 revela que as alterações não são proporcionalmente distribuídas entre os projetos. Enquanto o eixo x fixa os projetos, dos menos aos mais alterados, considerado o total de alterações, o eixo y informa sobre o percentual de dispositivos. A linha demarcada com quadrados serve como referência e indica como seria a reta caso não houvesse desigualdade entre os projetos. Se esse fosse o caso, por exemplo, $20 \%$ dos projetos contariam com $20 \%$ das alterações. O gráfico apresenta ainda outras três retas, representando a concentração das alterações propostas pela coalizão, pela 
oposição, e o total de alterações (soma dos dispositivos apresentados pela coalizão e pela oposição). Quando analisamos o total de alterações, podemos notar que há grande concentração de alterações em poucos projetos. Os projetos que fazem parte do decil superior no que diz respeito a alterações contam com cerca de $48 \%$ de todas as modificações. O padrão de alteração quando considerada somente a coalizão é ainda mais concentrado: $51 \%$ das alterações propostas por esse grupo tiveram como destino os $10 \%$ dos projetos mais alterados. Sobre a oposição, o comportamento é outro. Embora haja desigualdade entre os projetos, as alterações provindas de parlamentares oposicionistas se distribuem de maneira menos concentrada entre os projetos, com $30 \%$ das modificações concentradas nos $10 \%$ dos projetos mais alterados.

Gráfico 9 - Concentração de Dispositivos: Projetos mais alterados por grupo

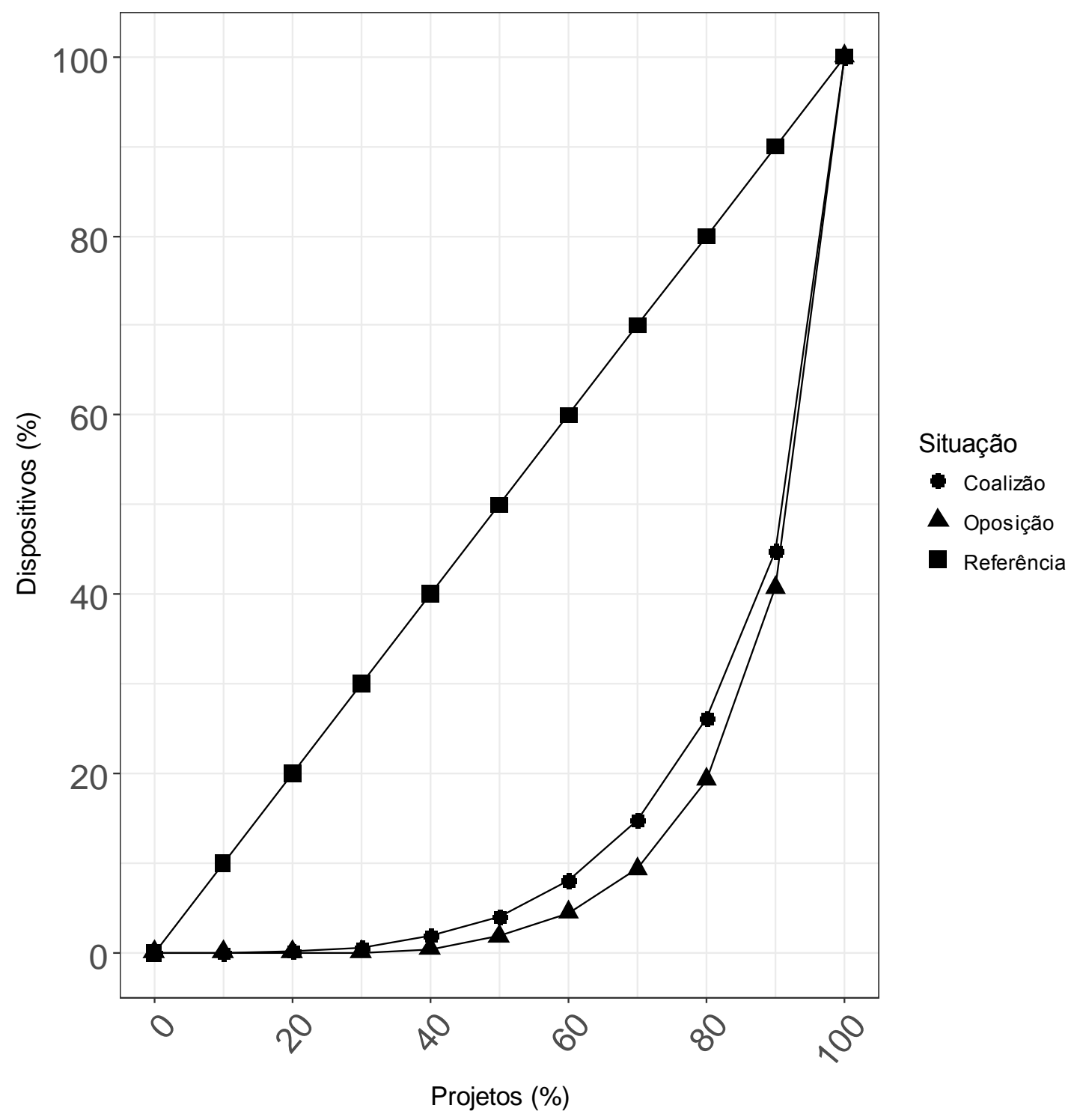

Fonte: Banco de Dados Legislativos do Cebrap 
No gráfico 9 as linhas referentes à coalizão e à oposição levam em consideração a ordenação dos projetos (dos menos aos mais alterados) para cada grupo. Ou seja, no caso da coalizão, os 309 projetos presentes na amostra foram ordenados tendo em vista as alterações propostas por apenas esse grupo. O mesmo foi feito para a oposição. Coalizão e oposição concentram 55\% e 59\% de suas alterações, respectivamente, em apenas $10 \%$ dos projetos mais alterados por seu grupo (31 projetos). Quando organizamos os dados dessa forma, percebemos que a oposição possui padrão mais concentrado do que a coalizão, diferentemente do gráfico anterior. Analisados os dois gráficos de concentração, o que podemos concluir? Quando as linhas que indicam a coalizão e a oposição possuem como referência os mesmos projetos (gráfico 8) a oposição possui menor concentração se comparada à coalizão. Quando as linhas são construídas tendo em vista as alterações realizadas para cada grupo, a oposição possui maior concentração. Podemos concluir que a oposição possui atuação concentrada, mas não nos mesmos projetos em que a coalizão foca suas modificações. Insisto. Os dois grupos concentram modificações em projetos diferentes. Ao contrário, apenas $16 \%$ dos projetos presentes na lista dos mais alterados (decil superior), tanto pela coalizão, quanto pela oposição, coincidem. 
Tabela 4 - Projetos mais alterados pela coalizão (decil superior)

\begin{tabular}{|c|c|c|c|}
\hline Projeto & $\begin{array}{c}\text { Dispositivos } \\
\text { Alterados }\end{array}$ & $\begin{array}{c}\text { Coalizão } \\
(\%)\end{array}$ & Resumo da Ementa \\
\hline PLP0018/99 & 1095 & 98,3 & Estabelece o regime de gestão fiscal responsável. \\
\hline MPV0255/05 & 581 & 100,0 & Prorroga o prazo para opção pelo regime de Imposto de Renda retido na fonte de Pessoa Física. \\
\hline MPV0656/14 & 455 & 94,4 & Reduz a PIS/PASEP, a COFINS, a PIS/Pasep-Importação e a Cofins-Importação sobre certos importados. \\
\hline PL.1627/07 & 363 & 99,5 & Dispõe sobre o Estatuto da Criança e do Adolescente. \\
\hline MPV0610/13 & 342 & 97,4 & Amplia o valor do Benefício Garantia-Safra para a safra de 2011/2012. \\
\hline MPV0472/09 & 341 & 92,2 & Institui o Regime Especial para o Desenvolvimento da Indústria Petrolífera. \\
\hline MPV0651/14 & 308 & 91,4 & Dispõe sobre os fundos de índice de renda fixa. \\
\hline MPV0497/10 & 282 & 100,0 & Promove desoneração destinadas à pesquisa tecnológica. \\
\hline MPV0413/08 & 246 & 97,2 & Aumenta para $15 \%$ a alíquota da (CSLL) das pessoas jurídicas de seguros privados e capitalização. \\
\hline PL.3846/00 & 245 & 87,8 & Cria a Agência Nacional de Aviação Civil - ANAC. \\
\hline MPV0619/13 & 245 & 90,4 & Autoriza a Companhia Nacional de Abastecimento a contratar o Banco do Brasil S.A. \\
\hline MPV0164/04 & 237 & 93,7 & Cria a contribuição para o PIS - PASEP - Importação e a COFINS - Importação. \\
\hline MPV0563/12 & 231 & 91,3 & Altera a alíquota das contribuições previdenciárias sobre a folha de salários. \\
\hline PL.5940/09 & 211 & 99,1 & Projeto do pré-sal que cria o Fundo Social - FS. \\
\hline PL.2142/96 & 206 & 100,0 & Dispõe sobre a política energética nacional. \\
\hline MPV0627/13 & 204 & 92,7 & Altera a legislação tributária federal. \\
\hline PL.4776/05 & 191 & 84,9 & Dispõe sobre a gestão de florestas públicas para produção sustentável. \\
\hline PEC0033/95 & 189 & 95,9 & Modifica o sistema de Previdência. \\
\hline PL.6673/06 & 189 & 99,0 & Dispõe sobre a comercialização de gás natural, projeto chamado de "Lei do Gás". \\
\hline MPV0502/10 & 186 & 99,5 & Institui a Bolsa-Atleta e cria os Programas Atleta Pódio e Cidade Esportiva. \\
\hline PLP0374/08 & 186 & 100,0 & Dispõe sobre o seguro rural para a proteção da produção agrícola e pecuária. \\
\hline MPV0517/10 & 160 & 99,4 & Institui o Regime o Desenvolvimento de Usinas Nucleares, entre outras disposições. \\
\hline PLP0184/04 & 154 & 100,0 & Institui a SUDECO. \\
\hline PL.1176/95 & 151 & 74,8 & Estabelece os princípios para o Sistema Nacional de Viação. \\
\hline MPV0559/12 & 148 & 98,7 & Autoriza a ELETROBRAS a adquirir participação na Celg Distribuição S.A. \\
\hline MPV0410/07 & 135 & 98,5 & Cria o contrato de trabalhador rural por pequeno prazo. \\
\hline MPV0339/06 & 134 & 94,4 & Instiui FUNDEB (Fundo de Manutenção e Desenvolvimento da Educação Básica). \\
\hline PEC0228/04 & 134 & 100,0 & Altera o Sistema Tributário Nacional. \\
\hline MPV0219/04 & 131 & 100,0 & Dispõe a apuração da CSLL e da Contribuição para o PIS/PASEP e COFINS não-cumulativas. \\
\hline MPV0066/02 & 123 & 78,3 & Medida Provisória chamada de "Minirreforma Tributária". \\
\hline PLP0076/03 & 120 & 100,0 & Institui a SUDENE. \\
\hline
\end{tabular}

Fonte: Banco de Dados Legislativos do Cebrap 
Os projetos mais alterados pela coalizão o são quase que exclusivamente apenas modificados por membros da base governista. Dentre os 31 projetos, apenas dois tiveram participação da oposição superior a $20 \%$ - um tratava sobre tributação e, quando votado, a coalizão governista possuía status minoritário ${ }^{12}$ e o outro, apresentado em 1995, foi aprovado apenas em 2011. O praticamente monopólio da coalizão sobre o conteúdo aprovado incidiu sobre projetos prioritários ao governo federal, na lista acima estão, por exemplo, o projeto do pré-sal, a conhecida PEC da Previdência do FHC, a PEC da Previdência e a reforma tributária do Lula, e os projetos que instituíram a SUDENE, a SUDECO, o FUNDEB e a ANAC.

\footnotetext{
${ }^{12}$ A coalizão governista era minoritária na data em que o projeto foi aprovado.
} 
Tabela 5 - Projetos mais alterados pela oposição (decil superior)

\begin{tabular}{|c|c|c|c|}
\hline Projeto & $\begin{array}{l}\text { Dispositivos } \\
\text { Alterados }\end{array}$ & $\begin{array}{l}\text { Oposição } \\
(\%)\end{array}$ & Resumo da Ementa \\
\hline MPV0079/02 & 165 & 100,0 & Dispõe sobre o ressarcimento dos custos de formação de atleta não profissional. \\
\hline MPV0014/01 & 134 & 100,0 & Dispõe sobre a expansão da oferta de energia emergencial e dá outras providências. \\
\hline MPV0615/13 & 124 & 77,0 & Autoriza o pagamento de subvenção aos produtores da safra 2011/2012 de cana-de-açúcar e de etanol. \\
\hline PL.2546/03 & 115 & 63,9 & Institui normas gerais para licitação de parceria público-privada no âmbito da administração pública. \\
\hline MPV0183/04 & 107 & 100,0 & Reduz as alíquotas do PIS/PASEP e da COFINS sobre fertilizantes. \\
\hline MPV0460/09 & 79 & 69,3 & Dispõe sobre construtoras do Programa Minha Casa, Minha Vida e concede atribuições à ANATEL. \\
\hline PEC0041/03 & 60 & 37,7 & Altera o sistema tributário nacional. \\
\hline MPV0664/14 & 58 & 45,7 & Estabelece regras para concessão do auxílio doença e pensão por morte. \\
\hline MPV0372/07 & 57 & 93,4 & Dispõe sobre a utilização de recursos em crédito rural oriundos da poupança rural. \\
\hline MPV0614/13 & 56 & 87,5 & Dispõe sobre a estruturação do Plano de Carreiras e Cargos de Magistério Federal. \\
\hline PL.1176/95 & 51 & 25,2 & Estabelece os princípios para o Sistema Nacional de Viação. \\
\hline PL.6272/05 & 49 & 76,6 & Dispõe sobre a Administração Tributária Federal. \\
\hline PL.5627/13 & 49 & 92,5 & Dispõe sobre o parcelamento e a remissão de dívidas patrimoniais com a União. \\
\hline MPV0127/03 & 47 & 100,0 & Dispõe sobre o Apoio às Concessionárias de Serviços Públicos de Distribuição de Energia Elétrica. \\
\hline PL.2205/11 & 46 & 100,0 & Cria cargos de Especialista em Infraestrutura Sênior, entre outros. \\
\hline MPV0214/04 & 44 & 100,0 & Dispõe sobre a introdução do biodiesel na matriz energética brasileira. \\
\hline PL.3077/08 & 39 & 56,5 & Dispõe sobre a organização da Assistência Social. \\
\hline MPV0321/06 & 37 & 78,7 & Cria regras para a desindexação da economia. \\
\hline MPV0024/02 & 35 & 100,0 & Dispõe sobre o Programa Especial de Crédito para Reforma Agrária - PROCERA. \\
\hline MPV0212/04 & 35 & 89,7 & Reorganiza as classes da Carreira Policial Federal, entre outras. \\
\hline PL.4776/05 & 34 & 15,1 & Cria o Fundo Nacional de Desenvolvimento Florestal - FNDF. \\
\hline MPV0441/08 & 34 & 36,2 & Dispõe sobre as Carreiras de Oficial de Chancelaria, entre outras. \\
\hline MPV0066/02 & 34 & 21,7 & Medida Provisória chamada de "Minirreforma Tributária". \\
\hline PL.2380/96 & 34 & 38,6 & Dispõe sobre o Fundo para o Desenvolvimento do Ensino Fundamental e de Valorização do Magistério. \\
\hline PEC0574/02 & 34 & 97,1 & Dispõe sobre as despesas do Poder Legislativo Municipal. \\
\hline PL.3846/00 & 34 & 12,2 & Cria a Agência Nacional de Aviação Civil - ANAC. \\
\hline MPV0595/12 & 32 & 29,1 & Dispõe sobre a exploração direta e indireta pela União de portos e instalações portuárias. \\
\hline PL.4205/01 & 31 & 96,9 & Altera o Código de Processo Penal: "Reforma Processual Penal". \\
\hline PL.4207/01 & 31 & 60,8 & Altera o Código de Processo Penal. \\
\hline MPV0532/11 & 30 & 78,9 & Dispõem sobre combustíveis e redução de emissão de poluentes por veículos automotores. \\
\hline MPV0472/09 & 29 & 7,8 & Institui o Regime Especial para a Indústria Petrolífera e ajusta o Programa Minha Casa Minha Vida. \\
\hline
\end{tabular}

Fonte: Banco de Dados Legislativos do Cebrap 
O padrão da oposição difere do observado no grupo da coalizão. Nos projetos mais alterados pela oposição (decil superior) há um equilíbrio maior entre a proporção do conteúdo da lei devido a cada grupo. Parte considerável dos projetos foram aprovados quando a coalizão não possuía maioria (cerca de $20 \%$ dos projetos da lista), entretanto, há um outro leque de projetos para os quais, nominalmente, a coalizão possuía número suficiente para aprová-los sozinha. Cabe ressaltar que 28, dos 31 projetos, são Medidas Provisórias ou Projetos de Lei Ordinária, cuja aprovação depende apenas de maioria simples. Se quisesse, a coalizão governista poderia ter afastado a intervenção oposicionista, como o fez em seus projetos prioritários. Por que não o fez? Porque, como discutido em seção precedente, a produção de políticas não é um jogo de soma zero, no qual o ganho de uns necessariamente representa a perda de outros. Não há qualquer motivo para esperarmos que a coalizão intervenha em todos os projetos em tramitação. Se não há conflito, não há razão para impedir que a oposição contribua.

\subsection{Conclusão}

O presente capítulo teve por objetivo requalificar o debate sobre a relação entre o poderio das comissões e a capacidade de intervenção de minorias e da oposição. As contribuições se dividem em duas modalidades, a primeira teórica, a segunda empírica. Buscou-se demonstrar que a expectativa da literatura, segundo a qual comissões fortes favoreceriam uma oposição também forte, estava baseada em solo teórico frágil, visto que desconsiderava o impacto do princípio majoritário no processo de tomada de decisões em Legislativos. Em solo empírico, o presente capítulo é mais um esforço de abertura da caixa preta do processo decisório e, por meio da análise do comportamento dos legisladores, buscou evidenciar que as previsões relativas à atuação da oposição no Brasil encontram pouco respaldo. 


\section{CAPÍTULO 2}

\section{O Princípio Majoritário Alcança os Procedimentos: Restrição ao Poder da Minoria}

Explicar o mecanismo que leva à mudança institucional não é tarefa fácil (HALL, 2010). Para os fins por mim propostos, quais sejam, explicar o timing e o sentido de reformas regimentais, argumento que a abordagem neo-institucionalista da escolha racional é capaz de oferecer um ferramental analítico de grande valia. A identificação de coalizões de atores e a especificação de seus interesses e estratégias serão os pilares da análise empreendida. Sem desconsiderar o impacto das regras herdadas, argumento que mudanças nas regras do jogo dependem da construção de coalizões de indivíduos cujas possibilidades de ganhos se alargam caso a nova regra seja adotada, em outras palavras, a mudança institucional é concebida como um resultado endógeno do processo de tomada de decisão por atores racionais.

Binder (1997), analisando as transformações regimentais responsáveis por afetar o poder de influência do partido minoritário nos Estados Unidos, edifica uma explicação que possui os dois elementos discutidos: cálculo racional e restrições advindas da estrutura institucional herdada. Em seu trabalho, a autora demonstra a maior plausibilidade da hipótese partidária - em oposição à explicação alternativa, que via no aumento da carga de trabalho a razão para a restrição dos direitos da minoria. A formulação de Binder é a seguinte:

Partisan hypothesis: The majority party will suppress minority rights when both majority and minority party preferences are highly cohesive and when the two parties are polarized over policy, encouraging the minority to adopt a strategy of obstruction (BINDER, 1997:47)

Seguem da hipótese partidária algumas condições a serem atendidas para que a restrição à capacidade de atuação da minoria se observe. Conforme o cânone da ciência política, instituições importam e afetam o resultado substantivo. As intensas disputas sobre regras deixam claro que, mais do que pela regra, a competição é pelos resultados esperados caso o novo procedimento seja instituído. Portanto, para que atores políticos incorram nos custos de adentrar na briga, uma política concreta deve estar no horizonte, cuja concretização, fossem as regras outras, encontraria caminho menos sinuoso. Como condição adicional, é preciso que o partido majoritário possua posicionamento coeso quanto à política a ser adotada após eliminado o empecilho regimental. Simetricamente, 
a agremiação minoritária também deve possuir coesão em relação à política, embora em sentido contrário. Dado o imperativo majoritário, mudanças regimentais não se fazem sem o concurso da maioria. Caso o partido majoritário não esteja unido quanto à política substantiva, não há como esperar que seus parlamentares votem juntos para modificar a regra que permitiria sua materialização. Por fim, a coesão do partido minoritário é também essencial visto que, sem a polarização sobre políticas, a minoria não incorreria na tática de obstrução, e a mudança regimental não seria necessária para o sucesso da agenda do partido majoritário.

Para Binder (1997), as mudanças responsáveis por restringir a capacidade de ação da minoria resultam de um cálculo imediatista do partido majoritário que, para ver aprovada sua agenda, altera os procedimentos utilizados pela oposição como arma de obstrução. Embora o papel das instituições herdadas seja de grande importância, impedindo que a trajetória de limitação ao poder da minoria observada na House of Representatives se reproduzisse, por exemplo, no Senado americano, a assertiva de Krehbiel (1992), segundo a qual regras, se prejudiciais à maioria, serão modificadas, encontra respaldo. O que se pretende aqui é uma discussão de cunho semelhante, aplicada ao Brasil.

O que proponho é analisar se os elementos elencados por Binder e outros que tratam do tema são capazes de lançar luz sobre importante reforma regimental ocorrida na Câmara dos Deputados, a saber, a reforma regimental que limitou a apresentação de Destaques para Votação em Separado (DVS). Para tanto, além desta introdução, o presente capítulo possui outras quatro seções. Na primeira, exponho o que são os destaques para votação em separado e os motivos que levaram à sua criação e posterior restrição. Na segunda, argumento que o timing das mudanças somente pode ser compreendido se adicionada à explicação a noção de poderes de agenda. Na terceira, discuto sobre a estabilidade de procedimentos que restringem o poder da minoria, argumentando que também estes somente podem ser explicados quando assumido o princípio majoritário. Por fim, a quarta seção conclui o capítulo.

\subsection{O princípio majoritário em ação na Câmara dos Deputados: O Destaque para Votação em Separado (DVS)}

O chamado Destaque para Votação em Separado (DVS) extrapolou a discussão procedimental e ganhou o centro do debate político em dois momentos. Primeiro, na Assembleia Constituinte, quando o DVS foi “inventado" pelo centrão para servir os fins 
do mesmo na sua tentativa de reverter decisões tomadas no âmbito da Comissão de Sistematização. Depois, no início do primeiro governo de Fernando Henrique Cardoso, quando a maioria que apoiava o governo atribuiu a demora na aprovação da PEC da previdência aos DVS apresentados pela oposição. Assim, nos dois casos, há uma inversão de quem valeu-se do recurso. Na constituinte, a maioria usou os DVS para reverter decisões da minoria, enquanto que no primeiro governo FHC, o DVS se tornou em arma da minoria para impor custos mais elevados à maioria.

Na Assembleia Nacional Constituinte, o Destaque para Votação em Separado (DVS) foi um dos elementos do Regimento Interno orquestrado pelo centrão que ganhou corpo na famosa resolução $n^{\circ} 3^{13}$. O DVS, quando concebido, tinha por objetivo servir à maioria da Casa, visto que, uma vez mobilizado, imputava os custos de angariação de votos àqueles desejosos de manter o texto constitucional tal qual emitido pela Comissão de Sistematização, composta por uma minoria (JOBIM, 1994; GOMES, 2006; MEDEIROS, 2013).

Além do DVS, outras inovações procedimentais vieram ao resgate do centrão, dentre as quais a possibilidade de apresentação de emendas de plenário para trechos inteiros - permitindo que o centrão não só eliminasse os trechos indesejados (por meio do DVS), mas também tivesse poder propositivo.

Embora haja dúvidas sobre o caráter enviesado à esquerda da Comissão de Sistematização (MEDEIROS, 2013), é notório que a disputa sobre as regras que disciplinariam os trabalhos constituintes se referia a aspectos substantivos do texto constitucional. O famoso levante do centrão, à luz de Binder (1997) e Krehbiel (1992), foi não apenas um movimento compreensível, mas, mais que isso, previsível. Conforme afirmam estes autores, uma maioria que, no decorrer do processo, adquire organização interna e alguma coesão sobre políticas, não permitiria que suas preferências fossem desconsideradas. Se a regra não serve à maioria, muda-se a regra.

Após a $\mathrm{ANC}^{14}$, o DVS volta ao centro do debate em 1995, primeiro ano de governo do então presidente Fernando Henrique Cardoso. A reforma regimental teve

\footnotetext{
13 A resolução $\mathrm{n}^{\circ} 3$ ganhou notoriedade por reunir um grupo suprapartidário, denominado como "centrão", em favor de uma mudança regimental que permitisse, dentre outras alterações, a apresentação de substitutivos inteiros ao projeto provindo da Comissão de Sistematização, além de instituir o Destaque para Votação em Separado (DVS), modificações que alteraram significativamente o andamento dos trabalhos constituintes. Para mais:

http://www2.camara.leg.br/atividade-legislativa/legislacao/Constituicoes_Brasileiras/constituicaocidada/assembleia-nacional-constituinte/fundo-assembleia-nacional-constituinte/saiba-mais...-2.2historia-administrativa

${ }^{14}$ Assembleia Nacional Constituinte (ANC).
} 
como combustível o conflito em torno da reforma da previdência. Notícias sobre a dificuldade enfrentada pelo governo para a aprovação da reforma previdenciária inundaram os jornais da época, chamando atenção para o contraste entre o amplo apoio no interior do Legislativo em favor da medida e os obstáculos enfrentados para aprovála. O motivo? Os DVS estariam sendo utilizados pela minoria para obstruir a matéria.

O que era o Destaque para Votação em Separado (DVS), quais eram as regras que disciplinavam seu uso e por que atrapalharam tanto o governo? Na Câmara dos Deputados a redação dos projetos de lei é votada em sua integralidade, havendo a possibilidade de serem ressalvadas as emendas e os destaques. Caso o projeto seja aprovado, em seguida ocorre a votação de emendas a trechos específicos que, caso rejeitadas, mantém o projeto tal qual aprovado inicialmente. Por endereçar partes do projeto, o Destaque para Votação em Separado se assemelha às emendas votadas após aprovado o projeto, todavia, com uma diferença crucial: na presença do DVS, todo o conteúdo do projeto é aprovado, exceto o trecho alvo do Destaque, de modo que, para ser incorporado, o trecho específico deve ser aprovado e, no caso de uma PEC, por maioria qualificada. O DVS, portanto, desmonta a votação em bloco, distribuindo o custo da aprovação da matéria por cada um de seus artigos destacados.

A votação do Projeto de Lei Complementar 223 de $1990^{15}$, assinado pelo deputado Nelson Jobim, exemplifica como os DVS podem parcelar um projeto até o ponto deste quase receber uma votação diferente para cada um se seus trechos. $\mathrm{O}$ projeto era uma tentativa de refrear o poder de que desfrutava o Executivo para apresentar Medidas Provisórias e ilustra a tensão na Câmara dos Deputados entre o PMDB e o então Presidente da República, Fernando Collor. Visando dificultar a aprovação da medida, os deputados governistas Arnaldo Faria de Sá (PRN/SP) e Paes Landim (PFL/PI) recorreram aos destaques para votação em separado. Em 06 de março de 1991 foi aprovada a subemenda substitutiva do então relator, documento que contava com 13 artigos. Não obstante a aprovação, 10 dos 13 artigos foram alvo de destaques, o que significa dizer que apenas 3 artigos foram efetivamente aprovados no dia 06. Os demais trechos foram votados individualmente. Os deputados governistas, ao imputarem aos opositores do governo o custo de angariar a maioria, evitaram que fosse aprovado, por exemplo, inciso que impedia a edição de Medida Provisória sobre matéria

\footnotetext{
${ }^{15}$ Numeração da Câmara dos Deputados.
} 
tributária, assim como frustraram a tentativa de setores oposicionistas de proibir a prática de reedição de Medidas Provisórias ${ }^{16}$.

Quando apresentada a PEC da Previdência ${ }^{17}$, em março de 1995, a coalizão governista contava com 289 cadeiras na Câmara dos Deputados (56,3\% da Casa) e, imediatamente após a primeira votação da Proposta, alcançou o número de 396 deputados (77,2\% da Casa), com a entrada do PPB para a coalizão, em abril de 1996. A PEC, contudo, só foi aprovada na Câmara dos Deputados e remetida ao Senado na segunda metade de julho de 1996. Os motivos? Não há dúvidas de que as dificuldades enfrentadas pelo governo na Comissão Especial atrasaram a tramitação da proposta. $\mathrm{O}$ substitutivo formulado pelo relator pmdebista Euler Ribeiro foi rejeitado, situação que levou o governo a torcer as regras procedimentais e então nomear outro relator de plenário. A manobra regimental foi contestada pela oposição, que recorreu ao Supremo Tribunal Federal (STF) por meio de um mandado de segurança. Ao fim, o STF deliberou em favor do governo, mas a intervenção do tribunal paralisou o andamento da proposta por quase um mês (FIGUEIREDO \& LIMONGI, 1999, cap. 7).

A resolução da disputa procedimental no Judiciário, porém, não eliminou todos os obstáculos que teriam de ser enfrentados pelo governo. Com apenas um décimo das assinaturas dos membros da Casa, a oposição se via capaz de apresentar um Destaque (DVS), o qual exigia três quintos de votos favoráveis para ser incorporado ao texto da PEC. O destaque conferia à oposição a capacidade de atrasar a aprovação da matéria, mas não só. O DVS imputava o ônus de angariar maioria à base governista, que precisava reunir seguidamente o mínimo de 308 votos, situação que exigia intensa coordenação. Com efeito, mais de três centenas de votos tinham de ser oferecidos nominalmente, expondo o posicionamento de cada um dos deputados sobre trechos específicos do texto, muitos dos quais sensíveis a grupos de interesses e bastante impopulares. Não somente atrasar, por meio dos destaques a oposição se via capaz de desarticular a coalizão majoritária e impedir a modificação do status quo constitucional.

Em setembro de 1995 a Mesa Diretora da Câmara propõe o Projeto de Resolução 60. Com ele, esperava-se que a maioria obtivesse caminho menos tortuoso e conseguisse, finalmente, a aprovação da reforma: se aprovado, os DVS dependeriam do crivo do plenário para serem aprovados. A real discussão do projeto na Câmara começa em junho de 1996 porém, na opinião pública se inicia antes, ainda em maio. Neste mês,

\footnotetext{
${ }^{16}$ Enviado ao Senado, O projeto não obteve aprovação nesta Casa.

${ }^{17}$ Trata-se da Proposta de Emenda Constitucional 33 de 1995.
} 
em artigo da Folha de São Paulo, intitulado "Empresários querem apressar reformas", são citados o presidente da CNI (Confederação Nacional da Indústria) e então senador, Fernando Bezerra, assim como o presidente da república, ambos em defesa da mudança regimental que viria a restringir o uso dos DVS:

[...] Bezerra afirmou que não considera antidemocrático rever normas do Congresso durante a tramitação das reformas. Cerca de 2.500 empresários foram ontem ao Congresso, segundo a CNI. "Isso não é mudar a regra com o jogo andando. Todo dia tem jogo novo", disse. Bezerra afirmou que "o aperfeiçoamento das regras tem que ser feito sem sair do campo democrático".

O presidente Fernando Henrique Cardoso também reclamou do regimento ao citar a reforma da Previdência.

"Vamos ter que votá-la outra vez, umas sete ou oito vezes, por causa do regimento da Câmara". No início da noite, o governo foi derrotado pela oposição na votação dessa reforma.

A defesa de mudança de regras para a tramitação das reformas foi feita em discurso ao presidente da Câmara, Luís Eduardo Magalhães (PFL-BA), e ao presidente interino do Senado, Teotônio Vilela Filho (PSDB-AL), em audiência dos empresários no Congresso.

"Temos pressa para as reformas. Que se mude as regras para votar mais rápido", afirmou Bezerra. Depois do discurso, ele explicou que estava se referindo "ao regimento da Casa, que obriga um processo muito lento" [Folha de São Paulo, 23 de maio de $1996^{18}$, adaptado].

Alcançado o mês de junho, o mesmo jornal publica mais um artigo, o quinto sobre o assunto no período, intitulado "Alterar Regimento é prioridade de FHC":

A alteração do Regimento Interno da Câmara para restringir o uso do DVS (Destaque para Votação em Separado) será priorizada pelo governo federal como forma de dar prosseguimento à reforma constitucional [...]. Hoje, para derrubar um DVS da oposição, o governo necessita de pelo menos três quintos dos votos dos parlamentares, em dois turnos de votação.

"Do jeito que está, não há democracia que funcione. A situação é absurda e precisa ser mudada para que as reformas prossigam", disse à Folha o ministro Luiz Carlos Santos (Assuntos Políticos).

Ele informou que a CCJC da Câmara está analisando um projeto de resolução que altera o regimento da Casa. Segundo Santos, o governo concentrará forças nessa votação.

\footnotetext{
${ }^{18}$ Link para a matéria: http://www1.folha.uol.com.br/fsp/1996/5/23/brasil/8.html
} 
Ele disse que o governo só vai esperar o fim do primeiro turno de votação da reforma previdenciária para alterar o regimento [Folha de São Paulo, 17 de junho de $1996^{19}$, adaptado].

Não há dúvidas de que promover a mudança do Regimento Interno era tarefa prioritária ao governo federal. Podemos, contudo, assumir de modo inequívoco que o DVS era um direito da minoria? Utilizando os critérios de Binder (1997), a resposta é sim. De acordo com a autora, dois critérios são suficientes para determinar quais aspectos procedimentais são favoráveis às minorias. São eles:

Minority identification standard: Rules advocated by the minority party to provide procedural advantages for the minority party qualify as minority rights (BINDER, 1997:23).

Effects Standard: Rules that have the effect of helping the minority party to challenge the majority qualify as minority rights, regardless of the original purpose or supporting coalition of the rule (BINDER, 1997:23)

A modalidade de Destaque para Votação em Separado (DVS) em vigor até 26 de junho de 1996, data de aprovação da reforma procedimental, se assumidos os critérios de Binder (1997), era, sem sombra de dúvidas, um direito da minoria. Quando analisada a tramitação do Projeto de Resolução, é possível notar que o posicionamento dos partidos excluídos da base governista, minoritários, é de contestação desde o dia um. Sete emendas foram apresentadas ao Projeto de Resolução e, além de possuírem em comum sua autoria - todas as emendas foram assinadas pelos líderes do PT, PCdoB, PDT, PSB, PPS e PL - também apresentavam enorme similaridade em suas justificativas: conter o ataque ao direito das minorias.

Não é justa a nova redação proposta no art. 161 do Regimento Interno no Projeto de Resolução $n^{\circ}$ 60/95, porque deixa inteiramente nas mãos da maioria a aprovação ou rejeição de um requerimento de DVS [...] (Justificativa à Emenda de Plenário 02, assinada pelos líderes do PT, PCdoB, PDT, PSB, PPS e PL. Diário da Câmara dos Deputados, 28 de outubro de 1995, p. 3368).

[...] O destaque de votação em separado é um instrumento democrático de alta relevância para a minoria ver seus pontos de vista submetidos à deliberação do Plenário. Submetê-lo à aprovação da maioria para que ele possa ser votado, como quer o Projeto de Resolução n 60/95, é, na prática,

\footnotetext{
${ }^{19}$ Link para a matéria: http://www1.folha.uol.com.br/fsp/1996/6/17/brasil/5.html
} 
impedir o contraditório, vital para a democracia (Justificativa à Emenda de Plenário 03, assinada pelos líderes do PT, PCdoB, PDT, PSB, PPS e PL. Diário da Câmara dos Deputados, 28 de outubro de 1995, p. 3368).

Está claro que o instrumento do DVS era reclamado pela minoria como um recurso seu por direito. Os destaques atendem ao primeiro dos requisitos, qual seja, o minority identification standard. Não apenas, se encaixam também no segundo, o effect standard. Provém dos líderes da maioria a alegação de que os DVS serviam como arma de obstrução da minoria.

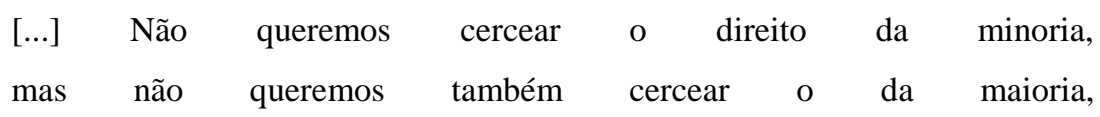
que é o que está ocorrendo. [...] Mas queremos um Regimento Interno em que prevaleça a vontade livre e soberana do Plenário. Em última análise, o Plenário é absoluto em suas decisões (Inocêncio de Oliveira, líder do PFL. Diário da Câmara dos Deputados, 27 de junho de 1996, p. 18441).

[...] E para nós foi uma imensa surpresa descobrir que o DVS, tal como existe hoje e no caso específico da reforma da Previdência, serviu para desfigurar completamente aquilo que a maioria tinha votado e aprovado anteriormente (José Aníbal, líder do PSDB. Diário da Câmara dos Deputados, 27 de junho de 1996, p. 18444).

Para que não restem dúvidas de que o destaque para votação em separado estava sendo utilizado como uma importante arma pela oposição e que esse foi o motivo que levou à sua limitação, é preciso que verifiquemos se, após a aprovação da Resolução 60 de 1995, os DVS perderam seu potencial de atrapalhar os anseios governistas no que diz respeito à PEC da Previdência.

Quadro Comparativo - Antes e depois da Aprovação do Projeto de Resolução 60 de 1995

Projeto de Resolução 60 de 1995

Antes da Aprovação

Após a Aprovação

Exigência Requerimento assinado por 1/10 da Casa ou líderes que de Quórum representem esse número
Requerimento assinado por 1/10 da Casa ou líderes que representem esse número, que deverá ser aprovado pelo Plenário

Sim, na seguinte proporção: de 5 até 24 deputados (1 destaque); de 25 até 49 deputados (dois destaques); de 50 até 74 deputados (três destaques); de 75 a mais deputados (quatro destaques)

Fonte: Elaboração própria, a partir do Regimento Interno da Câmara dos Deputados antes e após a aprovação do Projeto de Resolução 60 de 1995. 
Conforme parágrafos anteriores, a PEC da Previdência foi apresentada na Câmara dos Deputados em março de 1995 e promulgada em dezembro de 1998. O projeto de Resolução 60, por sua vez, obteve aprovação em junho de 1996, o que significa dizer que a referida PEC tramitou sob regras diferentes: primeiro, sem a restrição para a apresentação de destaques para votação em separado e, após junho de 1996, autorizando os destaques apenas nos casos em que estes fossem aprovados em plenário ou assinados pela entidade partidária - limitados em seu número de acordo com o tamanho das bancadas, conforme quadro comparativo. A mudança regimental afetou a dinâmica dos destaques para votação em separado na Câmara dos Deputados e, consequentemente, a tramitação de projetos de lei? A resposta é sim.

Na primeira passagem da PEC da Previdência pela Câmara o projeto foi alvo de 226 requerimentos de destaque. Embora ao final da primeira passagem do projeto pela Casa Baixa apenas 25 destes tenham efetivamente sido votados, isso ocorreu mais em razão de terem sido retirados por seus autores - em sua grande maioria, partidos oposicionistas - e menos por possíveis efeitos do Projeto de Resolução 60, já que o projeto foi aprovado apenas 21 dias antes da PEC ser encaminhada ao Senado Federal e depois da votação de todos os 25 destaques (FIGUEIREDO \& LIMONGI, 1999) ${ }^{20}$. O impacto da Resolução, se houver, deverá ficar evidente por meio da comparação entre as primeira e segunda passagens da PEC na Câmara.

Aprovada pelo Senado em outubro de 1997, e PEC retorna à Câmara dos Deputados, para que esta Casa se pronuncie acerca das modificações perpetradas pela Casa Alta. Em sua segunda passagem pelo crivo dos deputados, em fevereiro de 1998, 114 requerimentos de destaque simples considerados admissíveis pela Mesa precisavam ser considerados, dos quais um partiu da liderança do bloco parlamentar formado pelos partidos PMDB, PSD e PRONA, dois de deputados do PPB, um de deputado do PFL, um de deputado de PSDB e, finalmente, 108 foram assinados pelo vice-lider do bloco PT/PDT/PCdoB, o deputado Humberto Costa. Diferentemente do cenário de dificuldade que marcou a primeira passagem da PEC pela Câmara, a considerável quantidade de DVS não se configurou como um problema à maioria governista: os líderes do PSDB, PFL, PPB e bloco parlamentar PMDB/PSD/PRONA assinaram requerimento solicitando a votação em globo dos 114 destaques. Aprovado o requerimento, seguiu-se

\footnotetext{
${ }^{20}$ De acordo com Figueiredo e Limongi (1999), a retirada da maioria dos destaques apresentados pela oposição demonstra que a estratégia desse grupo não era simplesmente obstruir, mas sim forçar a base governista a explicitar sua posição sobre trechos sensíveis e, assim, dificultar que o governo obtivesse os votos necessários para alterar o status quo.
} 
à deliberação em bloco dos destaques, que foram todos rejeitados em uma única votação. À oposição restou utilizar de sua cota de destaques regimentalmente assegurada por meio dos partidos, condição que possibilitou a votação nominal de apenas cinco destaques assinados pelas bancadas do PT, do PDT, do PSB e do PCdoB, contra 20 destaques de autoria oposicionista votados na primeira passagem do projeto da Câmara, antes da aprovação do projeto de resolução.

Em conclusão, a alteração do Regimento Interno da Câmara dos Deputados permitiu que a maioria, antes obstruída por uma parcela diminuta da Casa, finalmente aprovasse aquela que seria uma das principais reformas do governo $\mathrm{FHC}$, a reforma da previdência.

\subsection{Quando ocorrerão reformas procedimentais? Explicando o timing das mudanças}

Krehbiel (1992) assinalou corretamente que procedimentos em desacordo com o preferido pela maioria são instáveis, visto que está ao alcance e é do interesse da maioria alterar este procedimento. O autor, entretanto, ao conceber o termo maioria de modo genérico, sem explicitar precisamente a qual maioria se refere, acaba por impedir testes empíricos claros e satisfatórios sobre suas proposições. Quando acontecerão reformas procedimentais? A falta de uma definição operacional do termo, argumento, foi deliberada e serviu como uma maneira de contornar a questão da multidimensionalidade de policies, deixada de lado por Krehbiel (1992). Explico.

O autor, para a criação de seu modelo preditivo, parte da suposição segundo a qual há apenas uma dimensão de política relevante. Se esse é o caso, é possível pensar nos conceitos maioria, de um lado, e minoria, de outro, apenas com recurso às preferências dos indivíduos. Se, contudo, decisões se dão em um espaço composto por várias dimensões, o parlamentar mediano em uma dimensão de policy não necessariamente o é em outra. Concretamente, isso significaria que, a depender da área de política, maiorias diferentes poderiam se formar e, se assim desejassem, seriam capazes de alterar as regras procedimentais (SHEPSLE \& WEINGAST, 1994). Diante deste cenário, uma possibilidade seria a ocorrência de ciclos, ao modo do Teorema do Caos de McKelvey (1976), afetando assim as próprias instituições (RIKER, 1980). A multidimensionalidade de preferências permite, entretanto, que conjecturemos um outro cenário possível, mas dessa vez a previsão é a estabilidade, e não mobilidade das instituições. 
Se as maiorias se alteram em função daquilo que é votado, não há uma maioria, mas várias. Mudanças institucionais demandam a existência de um grupo majoritário que veja nas novas regras vantagens em relação às existentes e então aja para alterar o status quo (BINDER, 1997). A existência de diversas maiorias dificulta o cálculo dos atores, visto que estes não conseguem avaliar se, no futuro, serão beneficiados ou prejudicados pelos novos procedimentos. É plausível supor que o ambiente de incerteza incentiva a estabilidade das instituições, e não os ciclos.

Para conseguirmos responder à pergunta de pesquisa proposta, qual seja, o impacto do princípio majoritário sobre os procedimentos, precisamos estabelecer se o Legislativo deve ser entendido como uni ou multidimensional e, se multidimensional, se deveríamos observar ciclos ou estabilidade institucional. Empiricamente, não há dúvidas de que o cenário político pode ter tantas dimensões quanto o número de decisões tomadas. Podemos assumir com segurança que, em princípio, estamos nos referindo a um universo multidimensional. Isso posto, devemos esperar por estabilidade ou ciclos? Nem uma coisa, nem a outra.

A presença dos partidos políticos faz com que um ambiente cujo potencial de dimensões é limitado apenas pelo número de decisões possa ser reduzido e explicado por apenas uma. Os partidos rompem com a independência entre as decisões, - e portanto, entre as dimensões - condicionando-as umas às outras. As diversas dimensões passam a se comportar como uma única, estruturada pelos partidos. Os ciclos não ocorrem porque agora é possível falar em uma maioria propriamente dita, a maioria partidária. A possibilidade de uma estabilidade absoluta também pode ser afastada, já que os partidos tornam possível a existência de um grupo coeso, capaz de analisar o futuro e decidir sobre mudanças procedimentais que o beneficie.

A questão central, portanto, se refere ao plano empírico, isto é, ao conhecimento quanto à importância e independências das diferentes dimensões políticas. Não só isto, ou talvez o que seja apenas outra forma de dizer o mesmo, depende do peso que os parlamentares dão às diferentes políticas.

A solução para conciliar a relativa estabilidade das instituições, de um lado, a um espaço multidimensional de políticas, de outro, se faz pela incorporação do partido político ao modelo. Embora não seja aqui assumida a noção de cartel, cabe à agremiação majoritária coordenar a maioria. As maiorias em cada setor de política 
podem variar, mas a entidade majoritária coordenadora, entendida como o partido majoritário, não ${ }^{21}$.

Seguindo a trilha de Cox e McCubbins (1993) e Binder (1997), é preciso notar que, no Congresso Americano, os direitos são concedidos em termos partidários ${ }^{22}$. Ao partido majoritário - e não a uma maioria genérica - são concedidas vantagens institucionais, como o cargo de chairperson nas comissões, o controle da Rules Committee e a função de Speaker. Simetricamente, ao partido minoritário, e não a uma minoria abstrata, são conferidos outros tantos direitos.

Krehbiel (1992) está certo ao vincular a mudança institucional ao princípio majoritário, porém não explica a origem da unidimensionalidade, característica essencial de seu modelo. A existência de uma única dimensão relevante, argumento, é originada pela ação dos partidos, considerados irrelevantes por Krehbiel (1992; 1993). O autor despreza o fato de que a maioria a que se refere possui nome próprio: é Democrata ou Republicana. Não se pretende com isso dizer que os dois partidos sejam absolutamente coesos e/ou que possuam preferências plenamente diferenciáveis entre si. Reconhece-se que, por diversas vezes, o parlamentar que ocupa a posição mediana em determinada área de política não pertence ao partido majoritário. Entretanto é preciso que também seja reconhecido que, se os direitos são concedidos por critério partidário, a coesão dos partidos deve ser levada em consideração se o objetivo é a previsão de mudanças procedimentais que afetarão os direitos da minoria (BINDER, 1997).

Insisto. É preciso que seja considerado que ao partido majoritário são conferidos poderes de agenda, capazes de reduzir os custos da angariação de maiorias. Poder de agenda se refere à capacidade de decidir quando e o que será apreciado pelo Plenário. Abaixo, seguem três modelos espaciais, cujo objetivo é evidenciar o impacto que a incorporação do poder de agenda na análise possui sobre a decisão esperada.

No primeiro, apenas uma dimensão é considerada e somente as preferências dos atores são levadas em consideração, em outras palavras, todos os indivíduos são colocados em pé de igualdade ou, se preferir, todos possuem o mesmo nível hierárquico. Nesse caso, apenas uma dimensão é considerada relevante e, para que sejam previstas tanto as políticas que serão aprovadas quanto os procedimentos que serão adotados, basta que seja conhecida a preferência mediana. A figura 1 apresenta

\footnotetext{
${ }^{21}$ É claro, o partido majoritário é alterado por meio de eleições.

${ }^{22}$ A relevância dos partidos enquanto solucionadores de dilemas de ação coletiva foi discutida por Cox \& McCubbins (1993). Assume-se a argumentação dos autores.
} 
um exemplo do exposto. Neste cenário, o ator A ocupa a mediana das preferências e sua posição estratégica permite que um projeto $(\mathrm{P})$ seja apresentado em exata sintonia com sua preferência, e aprovado com o apoio de C. Se essa é a distribuição e apenas uma dimensão importa, se soubermos as preferências de A e C, podemos prever quais serão as políticas e procedimentos adotados. Há apenas uma maioria (A e C) e uma minoria (B).

figura 1:

Unidimensionalidade e preferência

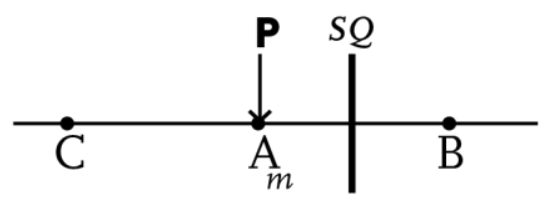

\section{legenda}

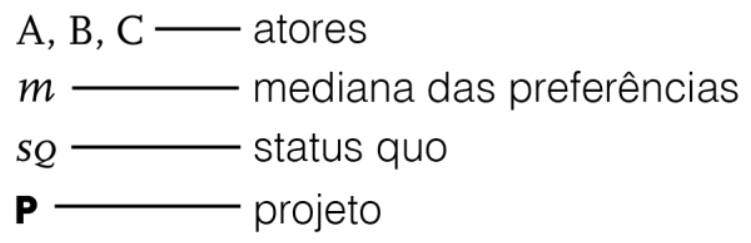

Figura 1

Fonte: Elaboração própria

No segundo modelo (figura 2), mantêm-se apenas as preferências dos atores, mas o modelo incorpora a noção de multidimensionalidade. Nesse cenário, os atores que ocupam a posição mediana em cada uma das dimensões variam, de modo que não é mais possível falar em apenas uma maioria, mas três. Simetricamente, não há somente uma minoria, mas também três. Se apenas as preferências sinceras regem o comportamento (KREHBIEL, 1993), o conhecimento da distribuição de preferências em cada uma das dimensões pode fornecer informações suficientes para prevermos onde projetos serão apresentados e aprovados, todavia, informam pouco sobre quais procedimentos serão adotados e quando direitos da minoria serão restringidos. Para possuir algum potencial preditivo, o modelo precisa especificar à qual maioria se refere. Ademais, mesmo do ponto de vista da política substantiva, o modelo só é útil se, de fato, apenas as preferências sinceras afetarem o comportamento, assertiva amplamente contestada, tanto nos Estados Unidos (Cox \& McCubbins, 1993), quanto no Brasil (FIGUEIREDO \& LIMONGI, 1999). 


\section{figura 2:}

\section{Multidimensionalidade e preferência}

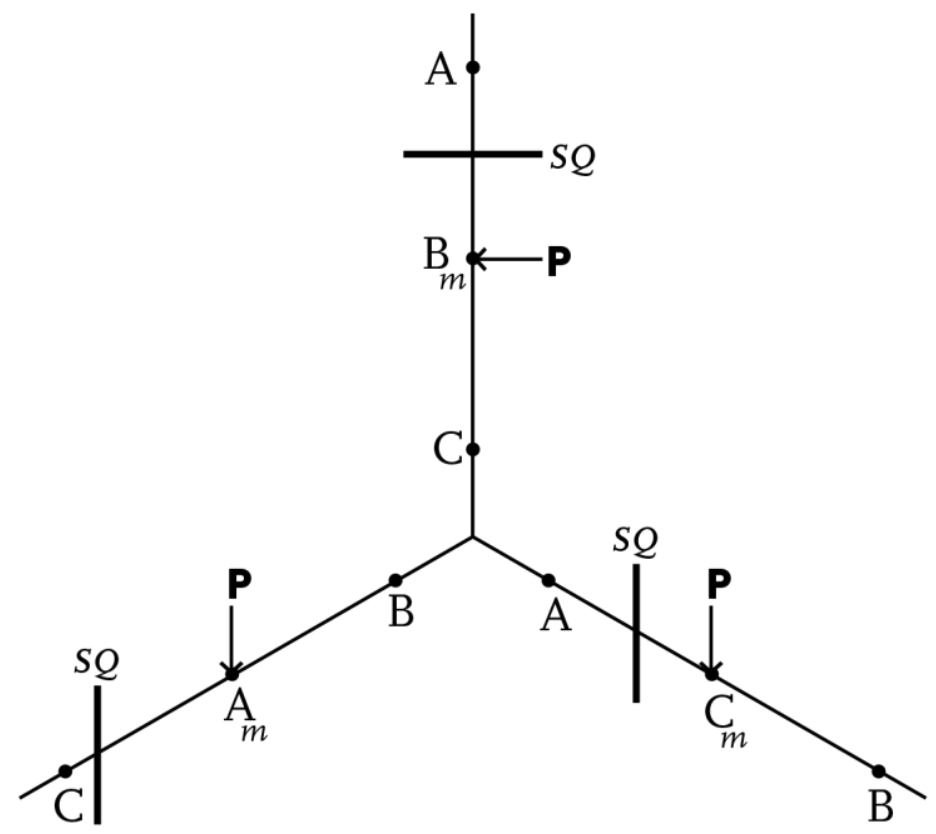

\section{legenda}

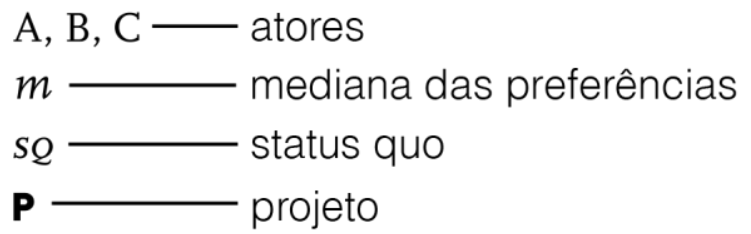

Figura 2

Fonte: Elaboração própria

Finalmente, o terceiro leva em consideração não apenas as diversas dimensões, mas também a presença de poderes de agenda. A figura 3 é a representação estilizada ${ }^{23}$ de uma realidade que incorpora tanto a noção de multidimensionalidade, quanto a de existência de poderes de agenda que, ao prever maiorias estáveis, ainda que em um cenário de mais de uma dimensão, foge à armadilha dos ciclos de decisão, sejam eles sobre policies ou instituições, e da imutabilidade institucional. Ainda que as preferências variem de acordo com o setor de política, os poderes de agenda à disposição do partido majoritário conferem a este um poder de barganha capaz de direcionar as políticas públicas em sua direção em grau mais elevado do que seria de se esperar caso fossem consideradas apenas as preferências. Na prática, as diversas

${ }^{23}$ Como todo e qualquer modelo, o aqui apresentado é limitado. As dimensões são tratadas como se independentes, o que implica na desconsideração do processo por meio do qual um ator cede em determinada área de política para ganhar em outra. Em outras palavras, desconsideram-se os "jogos ocultos" (TSEBELIS, 1998). Espera-se que, contudo, o modelo proposto seja útil. 
dimensões funcionam como se fossem apenas uma: o posicionamento partidário. $\mathrm{O}$ modelo é condizente com os achados empíricos de Zucco (2009) e Izumi (2016). Com isso não se pretende dizer que as preferências não importem, mas sim que estas são mediadas pelo poder de que dispõem os atores na arena decisória. No eixo inferior esquerdo, por exemplo, o poder de agenda de que desfruta o ator A lhe permite apresentar um projeto mais próximo de sua preferência do que seria o esperado, caso apenas as preferências afetassem o resultado. $\mathrm{O}$ ator $\mathrm{B}$, embora ocupe a posição mediana, por não possuir poder de agenda, não pode ameaçar, de modo crível, aliar-se ao $\mathrm{C}$ caso um projeto na posição mediana não seja apresentado, visto que não controla a pauta. A comparação dos segundo e terceiro modelos visa demonstrar que, embora as preferências sejam fundamentais (A, se quiser ver o projeto aprovado, não pode apresentá-lo em posição mais distante de B do que o status quo), o equilíbrio do sistema é diferente daquele caso somente as preferências regessem o comportamento. A assertiva, dado seu caráter abstrato, vale também para o caso brasileiro, real objeto de estudo deste trabalho. 


\section{figura 3:}

Multidimensionalidade e poder de agenda

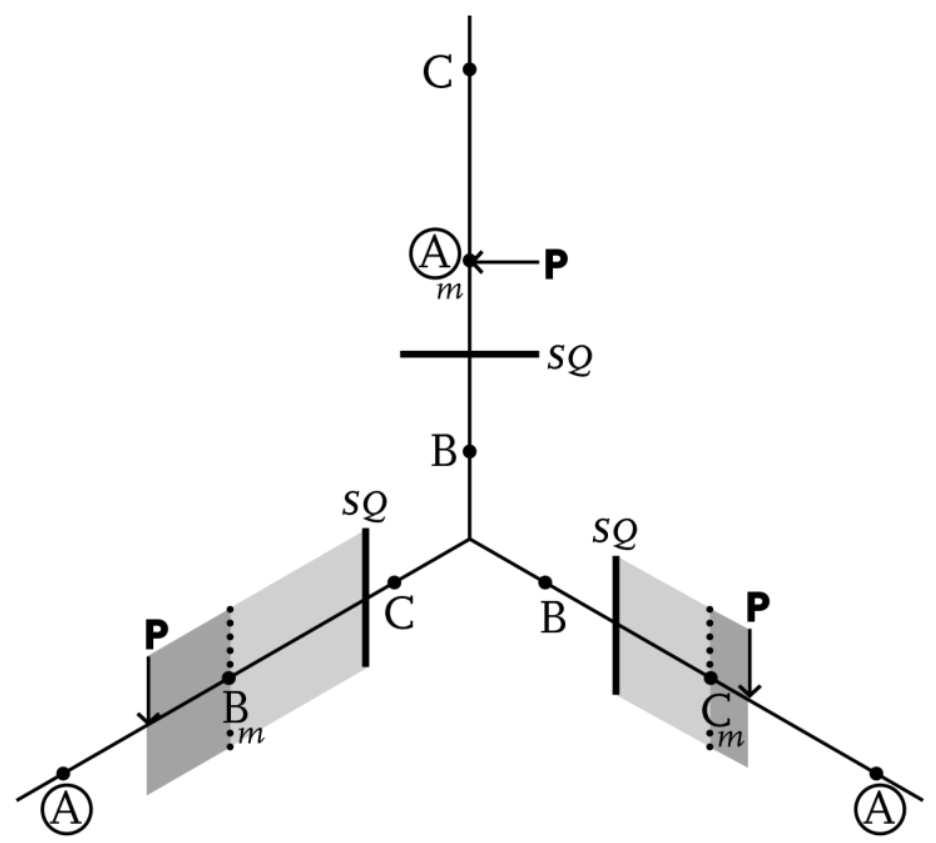

\section{legenda}

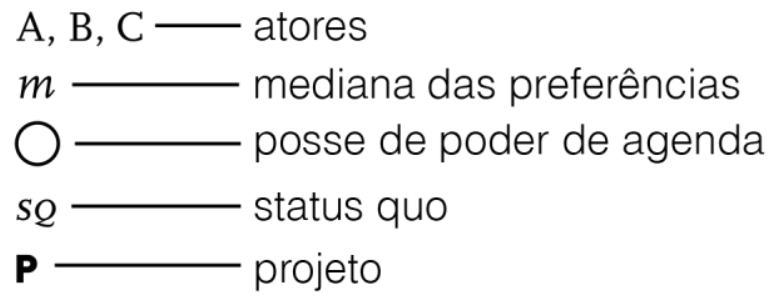

Figura 3

Fonte: Elaboração própria

Por aqui, a noção de partido majoritário deve ser substituída por outra, a de coalizão majoritária. Além da centralização do processo decisório no Congresso, responsável por distribuir poderes de agenda de acordo com critérios partidários, o caso brasileiro possui outro aspecto importante, capaz de conferir à coalizão de governo maior peso no processo de barganha. Refiro-me aos poderes legislativos do presidente. A coalizão, sempre formada pelo partido do presidente, possui à sua disposição mecanismos fora do alcance daqueles não membros da base governista. A formulação exclusiva do orçamento, as Medidas Provisórias, a urgência constitucional e o acesso aos cargos da administração pública federal são apenas algumas das ferramentas à disposição da coalizão governista (FIGUEIREDO \& LIMONGI, 1999). Para que a política pública encontre seu equilíbrio na posição mediana, é preciso que o ator mediano convença os sujeitos à sua direita e à sua esquerda de que, caso a política não 
seja oferecida em seu ponto preferido, formará uma nova aliança com o lado derrotado. Se o ator mediano, todavia, não possui poder de agenda para colocar em votação uma nova proposta que agrade mais a si e ao outro, que perdeu na rodada anterior, necessariamente deve arcar com o elevado custo de reunir uma coalizão grande o suficiente para acionar os mecanismos capazes de colocar um novo projeto na agenda, tornando a ameaça não crível. Isso permite que a coalizão governista imprima sua preferência em todas as dimensões de policy.

Com isso, pretendeu-se demonstrar que, com referência aos partidos, as previsões sobre restrições ao direito da minoria são mais acuradas. A restrição de direitos da minoria depende da existência de uma maioria estável e que possua uma agenda de políticas em comum. Se as maiorias, ainda que partidárias, são formadas $a d$ hoc, é plausível supor que as legendas se mostrem avessas à restrição de instrumentos passíveis de serem usados pela minoria, visto que a integram em diversos temas. No Brasil, limitar direitos da minoria, e mantê-los limitados, como será discutido na próxima seção, passa pela existência de uma coalizão majoritária estável ${ }^{24}$.

\subsection{Câmara dos Deputados: Uma Instituição Majoritária}

Antes, descreveu-se o processo que levou à contenção do uso do DVS pela minoria, agora, argumentarei que a estabilidade de três procedimentos responsáveis por cercear a minoria pode ser também compreendida se aceita a premissa segundo a qual o princípio majoritário é inviolável: tratam-se do recurso ao encerramento da discussão, da limitação a apenas uma votação nominal por hora e da conhecida urgência legislativa. Os três possuem em comum um elemento fundamental, a saber, estão à disposição dos líderes partidários. Assim como no Congresso americano, por aqui também são conferidas prerrogativas não à maioria, em sentido abstrato, mas às lideranças partidárias e à Mesa Diretora, instrumentos da maioria partidária. Se assumida a onipresença do princípio majoritário, não somente a criação, mas também a estabilidade de tais procedimentos tornam-se compreensível.

O Regimento Interno da Câmara dos Deputados, desde a sua primeira versão, promulgada em 1989, prevê o recurso ao encerramento da discussão. O instrumento pode ser requerido por cinco centésimos da Casa, ou líderes que representem esse

\footnotetext{
${ }^{24}$ Apenas sete das vinte e quatro coalizões formadas entre 1988 e 2014 foram minoritárias, sendo cinco dessas sete formadas antes de 1995, de modo que seja plausível defender se tratar de uma fase de aprendizado da então recém inaugurada democracia brasileira.
} 
número, mas deve ser aprovado em plenário para entrar em vigor ${ }^{25}$. Em outras palavras, se a maioria dos presentes em Plenário assim desejar ${ }^{26}$, encerra-se a discussão e o projeto recebe autorização para entrar em regime de votação ${ }^{27}$. O procedimento tem grandes implicações, visto que impede a ocorrência do conhecido filibuster, expediente por meio do qual parlamentares usam de seu direito de fala por extensos períodos com o objetivo de impedir a deliberação de matérias. Se nos modelos de decisão sobre o Congresso americano conhecer a preferência do filibuster é fundamental, dada a sua capacidade de impedir a votação da proposta, ainda que esta conte com o apoio do maior número ${ }^{28}$ (KREHBIEL, 1998), por aqui essa preocupação inexiste. Se o projeto conta com o número de votos mínimos estabelecidos para a sua aprovação, nada pode impedir a maioria de deliberar.

Na Câmara dos Deputados, obstruir a maioria não é tarefa fácil. Com o filibuster fora do campo de possibilidades, o recurso às votações nominais - uma possível maneira de atrasar os trabalhos e colocar a maioria em situação desconfortável, caso se deseje aprovar uma matéria impopular - seria de grande valia para a minoria como arma de obstrução. O Regimento Interno da Câmara dos Deputados permite que seis centésimos da Casa (trinta e um deputados), ou líderes que representem esse número, solicitem votação nominal a qualquer matéria. O número aparentemente pequeno esconde um complicador: se uma votação já tiver ocorrido, outra só será permitida por deliberação do plenário dentro do prazo de uma hora. A maioria, presente na Mesa Diretora e, portanto, conhecedora da pauta, comumente faz uso estratégico do procedimento e, para inviabilizar votações nominais indesejáveis, solicita antes uma votação nominal, retirando a possibilidade desse recurso à minoria (NICOLAU, 2000).

Finalmente, o requerimento de urgência coloca a última pedra sobre a capacidade de ação da minoria. De acordo com o Regimento Interno da Câmara, a urgência deve ser votada em Plenário e pode ser requerida, observado o limite máximo de dois projetos em regime de urgência, por (i) dois terços dos membros da Mesa, quando se tratar de matéria da competência desta, (ii) um terço dos membros da

\footnotetext{
${ }^{25}$ Regimento Interno da Câmara dos Deputados, seção IV - Do encerramento da discussão.

${ }^{26}$ Se o projeto estiver sob o regime de urgência, é necessária a anuência da maioria absoluta da Casa para o encerramento da discussão.

27 É preciso que o projeto tenha sido discutido por ao menos quatro oradores para que o requerimento de encerramento de discussão possa apresentado à Mesa.

28 Por exemplo, no caso do Senado americano, um requerimento semelhante ao nosso encerramento de discussão requer a aprovação de $3 / 5$ da Casa (Krehbiel, 1998;94). Desse modo, ainda que um projeto regimentalmente possa ser aprovado por maioria simples, o quórum necessário se estende para $3 / 5$ na ocorrência de um filibuster. Sem a reunião de $3 / 5$ dos votos da Casa, o projeto não segue para votação.
} 
Câmara, ou Líderes que representem esse número, ou (iii) dois terços dos membros de Comissão competente para opinar sobre o mérito da proposição ${ }^{29}$. A restrição a apenas dois projetos tramitando em regime de urgência é eliminada se o requerimento for solicitado pela maioria absoluta da Casa, ou líderes que representem esse número, caso no qual, se aprovado pela maioria absoluta do Plenário, o projeto é automaticamente incluído na Ordem do Dia para discussão e votação imediata ${ }^{30}$. O pedido de urgência, desse modo, permite à maioria decidir quase que instantaneamente sobre qualquer matéria, impedindo que minorias frustrem a votação.

Em conclusão, embora seja incorreto assumir, como faz Krehbiel (1992), que todo e qualquer procedimento em vigência no Legislativo conta com o apoio da maioria - a assertiva é problemática tanto porque parte do principle of remote majoritarianism, sem considerar que as maiorias não são unas, mas variam de acordo com a dimensão de policy (SHEPSLE \& WEINGAST, 1994:168), quanto por ignorar a possibilidade de instituições herdadas minarem a capacidade de ação da maioria no presente (BINDER, 1997) - o recurso ao princípio majoritário pode iluminar processos de mudança e de estabilidade institucional.

\subsection{Conclusão}

O presente capítulo buscou evidenciar que procedimentos antimajoritários são instáveis e, por esse motivo, passíveis de supressão. Utilizando como objeto de análise o projeto de lei que restringiu a utilização do Destaques para Votação em Separado (DVS) na Câmara dos Deputados e, como substrato teórico, a literatura sobre mudanças regimentais nos Estados Unidos, busquei tornar inteligível o momento no tempo em que se deu a reforma no uso dos DVS, bem como o motivo que animou os atores políticos a fazerem-na. Para que consigamos compreender a dinâmica responsável por ampliar ou limitar os direitos da minoria devemos nos atentar à onipresença do princípio da maioria e, mais do que isso, para o papel dos partidos políticos no que diz respeito à coordenação dos trabalhos legislativos. Argumentei que a presença de procedimentos ao alcance da maioria, como o recurso ao encerramento de discussão e o poder de urgência, são esperados e, mais que isso, que são utilizados pela maioria partidária para reduzir as diversas dimensões de política à uma única, determinada pelo partido. A conclusão para o caso americano se aplica também para o brasileiro: devemos esperar restrições aos

\footnotetext{
${ }^{29}$ Regimento Interno da Câmara dos Deputados, art. 154.

${ }^{30}$ Regimento Interno da Câmara dos Deputados, art. 155.
} 
direitos na minoria se uma maioria suficientemente coesa em torno de uma agenda de políticas estiver sendo obstruída por uma minoria. 


\section{CONCLUSÃO}

A discussão sobre quais seriam os mecanismos responsáveis por conferir à oposição poder de influência sobre o processo decisório está repleta de ambiguidades e imprecisões. Argumento que a desconsideração do princípio majoritário e a falta de rigor quanto ao uso dos conceitos minoria e oposição, e quanto à definição do caracterizaria uma estrutura de comissões como fraca ou forte, fizeram com que fossem criadas expectativas equivocadas sobre o comportamento dos atores, situação que impediu que o comportamento da oposição fosse compreendido.

A relação entre uma estrutura de comissões forte, de um lado, e a ocorrência de oposições atuantes, de outro, é amplamente defendida pela literatura. Para a abordagem distributivista, a divisão dos trabalhos legislativos entre comissões criaria a possibilidade para ganhos de troca, fazendo com que parlamentares abdicassem de sua prerrogativa para decidir sobre matérias que consideram desimportantes em troca de maior poder de decisão sobre temas de maior interesse para a sua constituency. A atuação em plenário seria de bom grado abdicada em favor da atuação no interior das comissões. Uma estrutura decisória descentralizada permitiria que políticas espelhassem as preferências dos membros da comissão e não as do plenário, criando assim resultados antimajoritários. Torna-se evidente que a explicação viola o princípio majoritário e, por esse motivo, é deficiente.

Influenciados pelos estudos distributivistas, trabalhos que defendem ser o partido político o agente coordenador do processo decisório também argumentaram que comissões fortes, entendidas como aquelas detentoras de capacidades institucionais para afetar legislação, são capazes de oferecer à oposição poder de influência. Argumento que os estudos associados à corrente partidária, ao transportarem as relações criadas pelos distributivistas para outros contextos, também ignoraram a onipresença do princípio majoritário e consequentemente deixaram de notar que as comissões são, portanto, irrelevantes para explicar a capacidade da oposição.

A ocorrência de uma estrutura de comissões influente é necessária para munir o Legislativo frente ao Executivo, mas nada informa sobre o poder da oposição. É preciso ter em mente que a regra da maioria é uma constante em todo e qualquer Congresso, e atinge tanto as decisões sobre políticas quanto as decisões sobre os procedimentos que regerão aquelas. Ainda que o Legislativo esteja munido de uma estrutura de comissões 
considerada forte, a maioria sempre possui meios para impedir que seja aprovada qualquer medida que ataque sua preferência.

Os dados sobre o Congresso brasileiro demonstram que a oposição não possui vantagens nas comissões em comparação com o plenário. Ao contrário, as comissões são amplamente utilizadas pela coalizão governista. Esse resultado nada tem a ver com uma possível fraqueza institucional das comissões brasileiras, supostamente causada pela intensa centralização do processo decisório, mas sim por estarem as comissões, assim como todos os aspectos institucionais de qualquer Legislativo, subordinados ao princípio majoritário.

A intervenção da oposição somente é possível quando esta passa a integrar a maioria e isso é verdade apenas em casos circunscritos. A extrema concentração de alterações oposicionistas a alguns poucos projetos, diferentes daqueles em que a coalizão concentra suas atividades, fornece indícios de que a oposição se faz mais presente em matérias não priorizadas pela coalizão. Ainda, ganha relevância no processo decisório em momentos de governo minoritário. A necessidade de angariação de votos torna necessária a incorporação de setores da oposição.

O mesmo é válido para mudanças procedimentais. Buscou-se demonstrar que regras que atentam contra os anseios majoritários são instáveis e, por esse motivo, pouco duradouras. A criação e posterior restrição dos Destaques para Votação em Separado (DVS) na Câmara dos Deputados exemplificam como a maioria possui meios para impedir que uma minoria frustre seus objetivos. Se a regra não serve à maioria, muda-se a regra. 


\section{REFERÊNCIAS}

ANDEWEG, Rudy B.; DE WINTER AND, Lieven; MÜLLER, Wolfgang C. Parliamentary opposition in post-consociational democracies: Austria, Belgium and the Netherlands. The Journal of Legislative Studies, v. 14, n. 1-2, p. 77-112, 2008.

ALDRICH, John H. Why parties?: The origin and transformation of political parties in America. University of Chicago Press, 1995.

ALDRICH, John H.; ROHDE, David W. The consequences of party organization in the House: The role of the majority and minority parties in conditional party government. In: Polarized politics: Congress and the president in a partisan era. 2000. p. 31-72.

ALMEIDA, Acir; SANTOS, Fabiano. Urgency petitions and the informational problem in the Brazilian Chamber of Deputies. Journal of politics in Latin America, v. 1, n. 3, p. 81-110, 2009.

AMES, Barry. Electoral Strategy under Open-List Proportional Representation. American Journal of Political Science, v. 39, n. 2, p. 406-433, 1 maio 1995.

AMES, Barry. Os entraves da democracia no Brasil. FGV Editora, 2003.

ARANTES, Rogério Bastos; COUTO, Cláudio Gonçalves;. Uma Constituição Incomum. In M.A.R. de Carvalho (Ed.), A Constituiçao de 1988: passado e futuro (pp. 17-51). São Paulo: Hucitec, Anpocs.

ARANTES, Rogério Bastos et al. Construção democrática e modelos de Constituição. Dados: revista de Ciencias Sociais, v. 53, n. 3, p. 545-585, 2010.

ARTER, David. Conclusion. Questioning the 'Mezey Question': an interrogatory framework for the comparative study of legislatures. The Journal of Legislative Studies, v. 12, n. 3-4, p. 462-482, 2006.

BINDER, Sarah A. Minority rights, majority rule: Partisanship and the development of Congress. Cambridge University Press, 1997.

CAMERON, Charles M. Veto bargaining: Presidents and the politics of negative power. Cambridge University Press, 2000.

CHEIBUB, Jose Antonio; LIMONGI, Fernando. From Conflict to Coordination: Perspectives on the Study of Executive-Legislative Relations. Revista IberoAmericana de Estudos Legislativos, v. 1, n. 1, p. 38-53, 2011.

COX, Gary W.; MCCUBBINS, Mathew D. Legislative leviathan: Party government in the House. Cambridge University Press, 1993.

COX, Gary W.; MCCUBBINS, Mathew D. Setting the agenda: Responsible party government in the US House of Representatives. Cambridge University Press, 2005.

DAHL, Robert Alan. Political opposition in western democracies. In: Comparative Government. Macmillan Education UK, 1969. p. 229-234. 
DAVIDSON, Roger H. Subcommittee government: New channels for policy making. In: The New Congress. Washington, DC: American Enterprise Institute for Public Policy Research, 1981. p. 99-133.

FIGUEIREDO, Argelina Cheibub; LIMONGI, Fernando. Executivo e Legislativo na nova ordem constitucional. Rio de Janeiro: Editora FGV, 1999.

FREITAS, Andréa Marcondes de. O presidencialismo da coalizão. Rio de Janeiro: Fundação Konrad Adenauer, 2016.

GIULJ, Sylvie. Confrontation or Conciliation: the Status of the Opposition in Europe. Government and Opposition, v. 16, n. 4, p. 476-494, 1981.

GOMES, Sandra. O impacto das regras de organização do processo legislativo no comportamento dos parlamentares: um estudo de caso da Assembleia Nacional Constituinte (1987-1988). Dados, v. 49, n. 1, p. 193-224, 2006.

GRIMMER, Justin; STEWART, Brandon M. Text as data: The promise and pitfalls of automatic content analysis methods for political texts. Political Analysis, p. mps028, 2013.

HALL, Peter A. Historical institutionalism in rationalist and sociological perspective. Explaining institutional change: ambiguity, agency, and power, p. 204224, 2010.

HELMS, Ludger. Studying parliamentary opposition in old and new democracies: Issues and perspectives. The Journal of Legislative Studies, v. 14, n. 1-2, p. 6-19, 2008.

IZUMI, Maurício. Governo e Oposição no Senado Brasileiro (1989-2010). Dados, v. 59, n. 1, p. 91-138, 2016.

JOBIM, Nelson. O Colégio de Líderes e a Câmara dos Deputados. O Desafio do Congresso Nacional: Mudanças Internas e Fortalecimento Institucional, Cadernos de Pesquisa Cebrap, (3).

KING, Anthony. Modes of Executive-Legislative Relations: Great Britain, France, and West Germany. Legislative Studies Quarterly, p. 11-36, 1976.

KREHBIEL, Keith. Information and legislative organization. University of Michigan Press, 1992.

KREHBIEL, Keith. Where's the Party? British Journal of Political Science, v. 23, n. 02, p. 235-266, 1993.

KREHBIEL, Keith. Pivotal Politics: A Theory of Pivotal Politics. 1998.

LAMOUNIER, Bolivar. Estrutura Institucional e governabilidade na década de 1990. In: REIS VELLOSO, J. P. DO (Ed.). . O Brasil e as Reformas Políticas. [s.1.] José Olympio, 1992.

LAMOUNIER, Bolivar. A Democracia Brasileira de 1985 à década de 90: a Síndrome da Paralisia Hiperativa. In: Governabilidade, Sistema Político e Violência Urbana. [s.1.] José Olympio Editora, 1994. 
LAVER, Michael; SCHOFIELD, Norman. Multiparty government: The politics of coalition in Europe. Oxford University Press, 1991.

LIJPHART, Arend. Patterns of democracy: Government forms and performance in thirty-six countries. Yale University Press, 1999.

LOWI, Theodore J. The end of liberalism: The second republic of the United States. Norton, 1979.

MAEDA, Ko. Determinants of opposition fragmentation: Parliamentary rules and opposition strategies. Party Politics, v. 21, n. 5, p. 763-774, 2015.

MARTIN, Lanny W.; VANBERG, Georg. Coalition policymaking and legislative review. American Political Science Review, v. 99, n. 01, p. 93-106, 2005.

MARTIN, Lanny W.; VANBERG, Georg. Parliaments and coalitions: The role of legislative institutions in multiparty governance. Oxford University Press, 2011.

MARTIN, Shane. Electoral institutions, the personal vote, and legislative organization. Legislative Studies Quarterly, v. 36, n. 3, p. 339-361, 2011.

MATTSON Ingvar, STRØM Kaare. Parliamentary committees. in Parliaments and majority rule in Western Europe. 1995:249-307.

MAYHEW, David R. Congress: The electoral connection. Yale University Press, 1974.

MAYHEW, David R. Divided we govern. Yale University, 1991.

MCKELVEY, Richard D. Intransitivities in multidimensional voting models and some implications for agenda control. Journal of Economic theory, v. 12, n. 3, p. 472-482, 1976.

MEDEIROS, Danilo Buscatto. Organizando maiorias, agregando preferências: a Assembleia Nacional Constituinte de 1987-88. 2013. Dissertação (Mestrado em Ciência Política) - Faculdade de Filosofia, Letras e Ciências Humanas, Universidade de São Paulo, São Paulo, 2013.

MEZEY, Michael L. The functions of legislatures in the third world.Legislative Studies Quarterly, p. 511-550, 1983.

MORGENSTERN, Scott; JAVIER NEGRI, Juan; PÉREZ-LIÑÁN, Aníbal. Parliamentary opposition in non-parliamentary regimes: Latin America. The Journal of Legislative Studies, v. 14, n. 1-2, p. 160-189, 2008.

NICOLAU, Jairo. Disciplina partidária e base parlamentar na Câmara dos Deputados no primeiro governo Fernando Henrique Cardoso (1995-1998). Red Dados, 2000.

PEREIRA, Carlos; MUELLER, Bernardo. Partidos fracos na arena eleitoral e partidos fortes na arena legislativa: a conexão eleitoral no Brasil. Instituto Universitário de Pesquisas do Rio de Janeiro, 2003. 
PEREIRA, Carlos; RENNÓ, Lúcio. O que e que o reeleito tem?: dinâmicas polâiticoinstitucionais locais e nacionais nas eleições de 1998 para a câmara dos deputados. Instituto Universitário de Pesquisas do Rio de Janeiro, 2001.

POWELL, G. Bingham. Elections as instruments of democracy: Majoritarian and proportional visions. Yale University Press, 2000.

RIKER, William H. The theory of political coalitions. Yale University Press, 1962.

RIKER, William H. Implications from the Disequilibrium of Majority Rule for the Study of Institutions. American Political Science Review, v. 74, n. 02, p. 432-446, 1980.

ROHDE, David W. Parties and Leaders in the Postreform House (American politics and political economy series). University of Chicago Press, 1991.

SAIEGH, Sebastian M. Active players or rubber stamps? An evaluation of the policymaking role of Latin American legislatures. C. SCARTASCINI, E. STEIN and M. TOMMASI, How Democracy Works: Political Institutions, Actors, and Arenas in Latin American Policymaking, p. 47-76, 2010.

SANTOS, Fabiano; ALMEIDA, Acir. Teoria informacional e a seleção de relatores na Câmara dos Deputados. Dados, v. 48, n. 4, p. 693-735, 2005.

SHEPSLE, Kenneth A.; WEINGAST, Barry R. The institutional foundations of committee power. American Political Science Review, v. 81, n. 01, p. 85-104, 1987.

SHEPSLE, Kenneth A.; WEINGAST, Barry R. Positive theories of congressional institutions. Legislative Studies Quarterly, p. 149-179, 1994.

STR ØM, Kaare. Minority government and majority rule. Cambridge University Press, 1990.

THIES, Michael F. Keeping tabs on partners: The logic of delegation in coalition governments. American Journal of Political Science, p. 580-598, 2001.

TORO-MAUREIRA, Sergio; HURTADO, Nicolás. The executive on the battlefield: government amendments and cartel theory in the Chilean Congress. The Journal of Legislative Studies, v. 22, n. 2, p. 196-215, 2016.

TSEBELIS, George. Jogos Ocultos: Escolha Racional no Campo da Política Comparada Vol. 17. Edusp, 1998.

TUTTNAUER, Or. Explaining parliamentary opposition behaviour. In: Second General Conference of the ECPR Standing Group on Parliaments Vienna, Austria. 2014. p. 26-28.

TUTTNAUER, Or. To Oppose or Not to Oppose: Comparing Parliamentary Oppositions and Their Behavior. In: 11th Annual Graduate Conference in Political Science, International Relations and Public Policy in memory of Yitzhak Rabin. 2015.

ZUCCO, Cesar. Ideology or what? Legislative behavior in multiparty presidential settings. The Journal of Politics, v. 71, n. 03, p. 1076-1092, 2009. 
ANEXOS

Anexo 1 - Lista de Siglas e Abreviações

Lista de Abreviaturas e Siglas

ANC Assembleia Nacional Constituinte

DEM Democratas

DVS Destaque para Votação em Separado

MPV Medida Provisória

PCdoB Partido Comunista do Brasil

PDS Partido Democrático Social

PDT Partido Democrático Trabalhista

PEC Proposta de Emenda à Constituição

PFL Partido da Frente Liberal

PL Projeto de Lei Ordinária

PL Partido Liberal

PLP Projeto de Lei Complementar

PMDB Partido do Movimento Democrático Brasileiro

PP Partido Progressista

PPB Partido Progressista Brasileiro

PPS Partido Popular Socialista

PR Partido da Republica

PRB Partido Republicano Brasileiro

PRN Partido da Reconstrução Nacional

PRONA Partido de Reedificação da Ordem Nacional

PSB Partido Socialista Brasileiro

PSD Partido Social Democrático

PSDB Partido da Social Democracia Brasileira

PSL Partido Social Liberal

PSOL Partido Socialismo E Liberdade

PT Partido dos Trabalhadores

PTB Partido Trabalhista Brasileiro

PV Partido Verde 
Anexo 2 - Coalizões governamentais no Brasil (1988-2014)

\begin{tabular}{|c|c|c|c|c|c|c|}
\hline \multirow{2}{*}{$\begin{array}{l}\text { Coalizão/ } \\
\text { Presidente }\end{array}$} & \multicolumn{2}{|c|}{ Data da Coalizão } & \multirow[t]{2}{*}{ Partidos da Coalizão } & \multirow[t]{2}{*}{ Evento de início da nova coalizão } & \multicolumn{2}{|c|}{$\begin{array}{l}\text { \% de Cadeiras do Partido do Presidente } \\
\text { na CD }\end{array}$} \\
\hline & Início & Fim & & & Início & Fim \\
\hline Sarney 2 & 06-out-88 & 14-mar-90 & 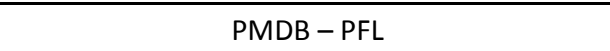 & Promulgação da Constituição & $40,8 \%$ & $31,9 \%$ \\
\hline Collor 1 & $15-$ mar-90 & 12 -out-90 & PRN - PFL & Eleição presidencial & $5,1 \%$ & $6,1 \%$ \\
\hline Collor 2 & 13-out-90 & 31-jan-91 & PRN - PFL - PDS & PDS entra & $6,0 \%$ & $5,8 \%$ \\
\hline Collor 3 & 01-fev-91 & 14-abr-92 & PRN - PFL - PDS & Eleição Legislativa & $8,2 \%$ & $6,2 \%$ \\
\hline Collor 4 & $15-a b r-92$ & $30-$ set-92 & PRN - PFL - PDS - PTB - PL & PTB e PL entram & $6,2 \%$ & $5,8 \%$ \\
\hline Itamar 1 & 01-out-92 & 30-ago-93 & PFL - PTB - PMDB - PSDB - PSB & Impeachment de Collor & $0,0 \%$ & $0,0 \%$ \\
\hline Itamar 2 & 31-ago-93 & 24-jan-94 & PFL - PTB - PMDB - PSDB - PP & PSB sai e PP entra & $0,0 \%$ & $0,0 \%$ \\
\hline Itamar 3 & 25-jan-94 & 31-dez-94 & PFL - PMDB - PSDB - PP & PTB sai & $0,0 \%$ & $0,0 \%$ \\
\hline FHCI 1 & 01-jan-95 & $25-a b r-96$ & PSDB - PFL - PMDB - PTB & Eleições presidencial e legislativa & $12,1 \%$ & $16,6 \%$ \\
\hline FHC I 2 & $26-a b r-96$ & 31-dez-98 & PSDB - PFL - PMDB - PTB - PPB & PPB entra & $16,6 \%$ & $18,3 \%$ \\
\hline FHC II 1 & 01-jan-99 & 05-mar-02 & PSDB - PFL - PMDB - PPB & Eleições presidencial e legislativa & $19,3 \%$ & $18,3 \%$ \\
\hline FHC II 2 & 06-mar-02 & 31-dez-02 & PSDB - PMDB - PPB & PFL sai & $18,3 \%$ & $18,3 \%$ \\
\hline Lula I 1 & 01-jan-03 & 22-jan-04 & PT - PL - PCdoB - PSB - PTB - PDT - PPS - PV & Eleições presidencial e legislativa & $17,7 \%$ & $17,5 \%$ \\
\hline Lula I 2 & 23-jan-04 & 31-jan-05 & PT - PL - PCdoB - PSB - PTB - PPS - PV - PMDB & PDT sai e PMDB entra & $17,5 \%$ & $17,5 \%$ \\
\hline Lula I 3 & 01-fev-05 & 19-mai-05 & PT - PL - PCdoB - PSB - PTB - PV - PMDB & PPS sai & $17,5 \%$ & $17,7 \%$ \\
\hline Lula I 4 & 20-mai-05 & 22-jul-05 & PT - PL - PCdoB - PSB - PTB - PMDB & PV sai & $17,7 \%$ & $17,5 \%$ \\
\hline Lula I 5 & 23-jul-05 & 31-dez-06 & PT - PL - PCdoB - PSB - PTB - PMDB - PP & PP entra & $17,5 \%$ & $15,8 \%$ \\
\hline Lula II 1 & 01-jan-07 & 01-abr-07 & PT - PR - PCdoB - PSB - PTB - PMDB - PP - PRB & Eleições presidencial e legislativa & $16,2 \%$ & $16,0 \%$ \\
\hline Lula II 2 & $02-a b r-07$ & 27-set-09 & $\begin{array}{c}\text { PT - PR - PCdoB - PSB - PTB - PMDB - PP - PDT - } \\
\text { PRB }\end{array}$ & PDT entra & $16,0 \%$ & $15,4 \%$ \\
\hline Lula II 3 & 28-set-09 & 31-dez-10 & PT - PR - PCdoB - PSB - PMDB - PP - PDT - PRB & PTB sai & $15,4 \%$ & $15,0 \%$ \\
\hline Dilma I 1 & 01-jan-11 & 01-mar-12 & PT - PR - PCdoB - PSB - PMDB - PDT - PP & Eleições presidencial e legislativa & $17,2 \%$ & $17,0 \%$ \\
\hline Dilma I 2 & $02-\operatorname{mar}-12$ & 02-out-13 & PT - PR - PCdoB - PSB - PMDB - PDT - PP- PRB & PRB entra & $17,0 \%$ & $17,2 \%$ \\
\hline Dilma I 3 & 03-out-13 & 31-dez-14 & PT - PR - PCdoB - PMDB - PDT - PP- PRB & PSB sai & $17,2 \%$ & $17,2 \%$ \\
\hline
\end{tabular}

\footnotetext{
${ }^{31}$ Fonte: Banco de Dados Legislativos do Cebrap.
} 